\author{
SERIES 'PULMONARY IMMUNE CELLS' \\ Edited by $U$. Costabel and $C$. Kroegel
}

\title{
Immunological functions of the pulmonary epithelium
}

\author{
A.B. Thompson*, R.A. Robbins*, D.J. Romberger*, J.H. Sisson*, \\ J.R. Spurzem*, H. Teschler**, S.I. Rennard*
}

Immunological functions of the pulmonary epithelium. A.B. Thompson, R.A. Robbins, D.J. Romberger, J.H. Sisson, J.R. Spurzem, H. Teschler, S.I. Rennard. (CERS Journals Ltd 1995.

ABSTRACT: The mature pulmonary epithelium forms a continuous lining to the airspace. Recent data suggest that this specialized epithelium may also contribute to host defence via interactions with inflammatory cells. Pulmonary epithelial cells can serve as part of the local immune system, providing structures and functions crucial for the maintenance of normal pulmonary function.

This article will briefly review the morphology and development of the pulmonary epithelial cells, their function with regard to host defence, alterations of the pulmonary epithelium associated with airway diseases, and potential therapeutic implications for the treatment of respiratory diseases.

Eur Respir J., 1995, 8, 127-149.

In health, the mature pulmonary epithelium forms a continuous lining to the airspace. Airway epithelial cells line the airway lumen and extend into the submucosal glands of the larger airways. Airway epithelial cells serve functions which contribute to defending the lungs against inhaled insults. These functions include provision of physical and functional barriers to and clearance of environmental agents, modulation of the inflammatory response to noxious stimuli, and regulation of the cellular activities necessary for responding to injury [1]. The alveolar compartment is likewise lined by epithelial cells. In the alveoli, the epithelial cells are specialized to serve the function of gas exchange. However, recent data suggest that the alveolar epithelium may also contribute to host defence via interactions with inflammatory cells. The pulmonary epithelium, thus, serves as part of the local immune system, providing structures and functions crucial for the maintenance of normal pulmonary function. Alteration of the structure and function of the pulmonary epithelium plays an important role in the pathogenesis of respiratory diseases.

This section of the series, "Pulmonary Immune Cells in Health and Disease", will briefly review the morphology and development of the pulmonary epithelial cells, their function with regard to host defence, alterations of the pulmonary epithelium associated with airway diseases, and potential therapeutic implications for the treatment of respiratory diseases.

\section{Morphology of the airway epithelium}

The mature airway is a complex structure lined by a continuous layer of epithelial cells. The distribution of
*Section of Pulmonary and Critical Care Medicine, Dept of Internal Medicine, University of Nebraska Medical Center, Omaha, Nebraska. **Division of Pneumonology, Ruhrlandklinik, Medical Faculty, University of Essen, Essen, Germany.

Correspondence: A.B. Thompson, Section of Pulmonary and Critical Care Medicine, Dept of Internal Medicine, University of Nebraska Medical Center, 600 S 42nd St, Omaha, Nebraska 68198-5300

Keywords: Airway, chemotaxis, epithelial cells, immunology, inflammation, morpho$\log y$

Received: September 14 1994; accepted after revision October 251994 cell types within the epithelium varies along the airway. Whilst as many as 49 cell types have been recognized in the airway [2], many of these may represent intermediate or differentiating cells, and a smaller number of cell types constitutes the bulk of the epithelium [3, 4]. On the surface of the epithelium of the proximal lower respiratory tract, ciliated cells predominate. Together with basal cells and a small percentage of goblet cells, the ciliated cells form a pseudostratified epithelium, with ciliated cells occupying the majority of the luminal surface and basal cells in contact with much of the basement membrane. The surface epithelium extends into the ducts of the mucosal glands, where it is characterized by a variable proportion of ciliated and mucous cells [5]. The specialized secretory epithelium of the submucosal gland is composed of serous cells and mucous cells. In the distal airway, Clara cells and basal cells predominate, cilia are not present, goblet cells are less numerous, and the epithelium has a more columnar appearance [6, 7]. At the alveolar level, the columnar epithelium gives way to a thin epithelium predominantly comprised of Type I cells, interspersed with Type II cells [8]. Each of the major cell types in the airway epithelium has distinctive histological characteristics.

Ciliated cells are characterized by prominent cilia, which attach by extension of axonemal microtubules (see below) to the basal body, which can be used to cytologically identify exfoliated ciliated cells in cases of ciliacytophoria [9]. Mucociliary clearance is the major function of the ciliated cells. Cilia are bathed in and extend through the thin, watery sol phase of airway secretions, into the gel phase, where specialized barblike structures on the tips of the cilia [10] grab the mucus 
during the active stroke phase of cilia beating, but not during the backward or relaxation stroke phase; and, thereby, propel the mucus with a rowing-like action. Ciliated cells possess $200-250$ cilia per cell $[2,11]$. In the human, the cilia are $0.25 \mu \mathrm{m}$ in width, and range from $6 \mu \mathrm{m}$ in length in the proximal airways to 3.6 $\mu \mathrm{m}$ in seventh generation airways [12]. The axoneme of the cilium contains the elements necessary for the conversion of chemical energy into mechanical force [13]. Dynein complexes, complexes of high molecular weight enzymes with adenosine triphosphatase activity, catalyse hydrolysis of adenosine triphosphate and transduce the energy into mechanical force in the form of ciliary bending [14]. The appropriate orientation of the direction of the beating of the cilia is related to the orientation of the structural elements of the axoneme. The axoneme of the cilium is made up of an outer ring of nine microtubule doublets surrounding a central pair. The microtubules are tethered, and their orientation maintained, by nexin links (between adjacent outer ring microtubule doublets) and radial spokes (between outer ring microtubule doublets and the central pair of tubules). This tethering restricts ciliary bending to a fixed orientation. The cilia in a given cell and its neighbours share a common orientation, and the beating of the cilia is maintained in an effective, metachronous state by cell-cell interactions, presumably, in part, via gap junctions.

Goblet cells contain large granules of varying electron density interspersed with few cytoplasmic inclusions. The nucleus is displaced away from the apical surface, and the cell tapers as it extends basally, giving the cell its typical goblet shape [15]. The goblet cell secretory granules are large, about $800 \mathrm{~nm}$ in diameter, and contain predominantly neutral mucins and sulphomucins. However, the content of the goblet cells is somewhat variable, with areas of the airway containing goblet cells rich in sialomucins. Goblet cells make up $15-25 \%$ of the surface epithelium in the proximal airways, decreasing in number distally [16-19].

Basal cells are flattened, pyramidal-shaped cells with a small cytoplasmic/nuclear ratio. The presence of basal cells underlying the ciliated and goblet cells, in part, lends the airway epithelium its pseudostratified appearance. The surface of the basal cells is rich in desmosomes, which attach to surrounding epithelial cells, thereby anchoring them to the basement membrane [20].

The epithelial cells which line the submucosal glands also have a typical anatomical distribution [3]. The submucosal gland has a duct of variable length lined with both serous and goblet cells, and connects to lobules. The lobules are lined with mucous and serous cells. In health, the ratio of mucous cells to serous cells is about $2: 1$, and is quite constant throughout the airways [5]. The serous cells tend to occupy the most distal portion of the glands, with the mucous cells lying more proximal to the ducts. This arrangement allows the less viscous secretions of the serous cells to flush out the thicker, more tenacious secretions from the mucous cells. Accompanying the lobules are myoepithelial cells. The myoepithelial cells extend from the serous cell rich terminus of the lobule to the duct, and presumably contract to expel glandular secretions into the airway lumen [21].

Clara cells compose the majority of cells in the bronchiolar epithelium. They are columnar shaped cells, with apical surfaces which bulge into the airway lumen. Ultrastructurally, the cell has a centrally placed, indented nucleus, prominent Golgi apparatus and rough endoplasmic reticulum $[22,23]$. Apically, the cell contains membrane-bound, electron-dense secretory granules. The ultrastructure of Clara cells and histochemical studies suggest that the cell is active in the secretion of proteins. Specifically, CC10 is a low molecular weight protein which, although not unique to Clara cells within the lung [24], appears to be the major secretory product of Clara cells [25]. The role of this protein is not wellestablished, but it has been postulated to have possible anti-inflammatory activities as an inhibitor of elastase [26], or phospholipase $A_{2}$ [27]. The Clara cell may also be active in the secretion of surfactant, as surfactantrelated glycoprotein has been identified within the cell [28]. In addition to secretion of biologically active substances, Clara cells may participate in clearance of noxious agents via the detoxification of inhaled substances [29].

In addition to the more common cell types described above, the normal airway epithelium has a small number of neuroendocrine cells. Neuroendocrine cells typically lie in the basal portion of the epithelium, but usually have thin cytoplasmic projections which extend to the lumenal surface $[30,31]$. Neuroendocrine cells increase in number from the largest bronchi to reach maximal density in the bronchioles [32]. More distally, neuroendocrine cells are rarely found in the terminal bronchioles [33]. The cells occur singly and in clusters termed neuroepithelial bodies, and tend to be concentrated at the bifurcations of the conducting airways. The neuroendocrine cell is distinguished by cytoplasmic neurosecretorylike granules. These granules localize to the basal surface of the cell, and range 70-150 nm in size. By electronmicroscopy, the granules have an electron-dense core, which is separated by an electron-lucent rim from the organelle's outer membrane [34]. The neuroendocrine cells are a rich source of bioactive secretory products, including bombesin-like activity (gastrin-releasing peptide), somatostatin, endothelin, serotonin, and calcitonin [34].

The role of neuroendocrine cells in the healthy lung is not clear but consideration of the fact that they are part of the neuroendocrine system (as defined by the unique appearance of the secretory granules, and the contents thereof) would suggest regulatory roles for these cells [32, 34]. The localization of the body of the cells to the basement membrane, the basal distribution of their granules, and the contents of their secretory granules, would suggest regulatory roles for secretion, smoothmuscle function, and cell growth modulation. In addition, the close association with neuronal cells, and the degranulation of the cells which occurs in response to hypoxia, hypercarbia, and hyperoxia, has lead to the suggestion that the neuroendocrine cell may act as an 
airway chemoreceptor [34]. Moreover, hypertrophy of neuroendocrine cells occurs in association with residence at high altitude [35], and in association with a number of pulmonary diseases, particularly in cigarette smokers [36]. A recently described syndrome of neuroendocrine cell hyperplasia in nonsmoking patients without other lung diseases underscores the potential importance of these cells for normal lung health. Patients with neuroendocrine cell hyperplasia were found to have multiple carcinoid tumorlets, and, importantly, peribronchiolar fibrosis with obliteration of small airways [36].

The epithelial cells which line the alveoli are specialized cells, whose main function is to permit gas exchange. Type I cells are thin, flattened cells, which by their attenuated shape permit efficient gas exchange. Type I cells cover $95 \%$ of the alveolar surface and have a paucity of organelles [8]. Type II cells are cuboidal in appearance. Their apical surface is covered with microvilli and their cytoplasm is notable for numerous lamellated inclusions. The lamellated inclusions are composed of lipids (predominantly phospholipids) and proteins [37-40]. They are secreted onto the apical surface of the alveolar epithelium to form surfactant. Surfactant acts to reduce alveolar surface tension and one of its constituents, surfactant protein-A (SP-A) has recently been noted to also have potentially important immunomodulatory activities (reviewed below).

The airway epithelium rests upon a connective tissue substrata consisting of a basement membrane, lamina propria, muscularis mucosa, and submucosa. The lamina propria contains a network of fine capillaries, a reticular connective tissue meshwork, and well-developed elastic tissue [41]. The submucosa consists of a denser extracellular matrix and contains the submucosal glands and the cartilaginous structures which lend support to maintain airway patency. Importantly, within the connective tissue matrix lie stromal cells, fibroblasts and smooth muscle cells, as well as cells which may participate in an inflammatory response, mononuclear cells, lymphocytes, neutrophils, eosinophils, mast cells, and Langerhans' cells. The close proximity of these cellular components of the airway walls to the airway epithelium make them targets for paracrine modulation by epithelial cells.

In the alveoli, the interstitium is thin in support of gas exchange. The close apposition of alveolar epithelial cells and the alveolar capillaries has functional and morphological implications. The very small distance between the Type I cell apical surface and the endothelial surface of the capillary minimizes the distance which gases need to diffuse through tissue [42, 43]. Moreover, the juxtaposition of alveolar epithelial cells with alveolar capillary cells seems to be crucial for the development of the Type I morphology [44].

\section{Development and differentiation of pulmonary epithelial cells}

The intrauterine development of the lungs is generally considered as two processes, the development of the conducting airways and the development of the gasexchange, terminal respiratory units. The bronchial structure is developed by the 16th week of gestation [45]. Until the 16th week, the primordial segmental airways undergo repeated divisions until more than the usual number of airway generations found in the adult lung have been formed [46]. Transformation of distal conducting airways into respiratory bronchioles then ensues, leading to loss of distal generations of conducting airways. At birth, the tracheobronchial structures are complete. In contrast, the development of acinar structures begins late in gestation and continues after birth. Alveolar development begins at 30-32 weeks gestational age and continues to term. Recognizable alveolar structures are present at birth, but differ enough from adult structures that the term "saccules" has been applied to differentiate them from the mature anatomical unit. By two months post delivery, morphologically mature alveoli appear [47]. The number of alveolar structures increases exponentially from weeks $30-32$ to term, so that at birth the estimated gas-exchange area is $3-4 \mathrm{~m}^{2}$. Within this anatomical framework, the pulmonary epithelium develops structurally and provides functions felt to be important for the normal development of the lungs.

The epithelium of the conducting airways first appears as primitive, pluripotent foetal cells, recognizable as epithelial cells by the presence of tight junctions and desmosomes [48]. The airway develops differentiated epithelial cells, at first centrally in the trachea, and then progressively distally. Basal cells, identified morphologically, are found at 10 weeks. They overlie the basement membrane and may serve as a precursor to more differentiated cells, quickly giving rise to ciliated cells and goblet cells in the central airways [48]. More distally, a cell of intermediate appearance has been postulated to be the precursor cell which gives rise to differentiated Clara cells and ciliated cells [48]. Goblet cells first appear during the 13th gestational week in the trachea and proximal bronchi. Their numbers increase with further appearance of goblet cells towards the periphery, but not reaching the proximal bronchioles [41]. Submucosal glands appear at 10 weeks in the trachea and 16 weeks in the bronchi. Fully formed cilia and mucus are found in the airways by 13 weeks. Neuroendocrine cells develop throughout the airways by week 16 [49].

Type I and Type II cells develop from endodermal origins [36]. During both the glandular and canalicular stages, the primordial alveoli are lined by cells identified as epithelial by the presence of gap junctions and tight junctions $[50,51]$. Type II cells can be identified by their lamellar inclusions, histochemical reactivity with monoclonal cell-specific and surfactant-related proteinspecific antibodies and by in situ hybridization with surfactant associated protein messenger ribonucleic acid (mRNA) at about week 24 [52-54]. Fully mature lamellar bodies develop only late in gestation, weeks 30-32. The development of mature lamellar bodies in sufficient numbers to support pulmonary function in the newborn is dependent upon hormonal signalling, especially by glucocorticosteroids [55, 56]. The Type I cells appear in the saccular stage. They can be distinguished by their 
attenuated morphology, and appear to be derived from Type II cells [57, 58]. The differentiation of Type I cells may be directed by interactions with pulmonary endothelial cells. In the foetal rat lung, direct contact of alveolar epithelial cells with endothelial cells has been associated with loss of lamellar bodies from Type II cells, attenuation of the cellular morphology, and fusion of the epithelial basal lamina with the endothelial basal lamina [44].

The developing pulmonary epithelium contributes important functions to normal lung development. The pulmonary epithelium is central to the secretion of fluid by the neonatal lung, and is integral to the secretion of surfactant. The neonatal lung is a secretory organ. In foetal lambs, 2-3 $\mathrm{ml} \cdot \mathrm{h}^{-1} \cdot \mathrm{kg}$ of fluid is secreted [59]. The fluid secreted by the lungs flows to the oropharynx by mass movement, as the result of foetal respiratory movements [60], and by contraction of airway smooth muscle [61]. The expelled fluid is added directly to the amniotic fluid or is swallowed. Analysis of the fluid secreted by foetal lambs demonstrates that the fluid is relatively rich in $\mathrm{K}^{+}$and $\mathrm{Cl}^{-}$, and poor in protein, $\mathrm{HCO}_{3}^{-}$ and $\mathrm{Ca}^{2+}[62]$. The protein content of foetal pulmonary secretions is approximately 10 fold lower than plasma or lymph, suggesting that the epithelium is impermeable to macromolecules early in development. The ionic composition of foetal lung fluid led to the suggestion that fluid secretion in the foetus results from active transport of $\mathrm{Cl}^{-}$in excess of the uptake of $\mathrm{HCO}_{3}^{-} \cdot \mathrm{Na}^{+}$ ion flux was hypothesized to follow the electrical gradient resulting from the transport of $\mathrm{Cl}^{-}$, and water flux to follow the resulting osmotic gradient. These suppositions have been confirmed in various experimental models of the developing lung.

Explants of first- and second-trimester human foetal lung tissue demonstrate cyclic adenosine monophosphate (cAMP)-stimulated fluid secretion [63, 64]. Using submersion explant culture of foetal rat lung, a model which maintains the early foetal phenotype of pulmonary epithelial cells, fluid secretion has been further characterized [65]. Fluid production was found to be dependent upon $\mathrm{Na}^{+} / \mathrm{K}^{+}$-adenosine triphosphatase (ATPase) secretion of $\mathrm{Cl}^{-}$. The cystic fibrosis transmembrane conductance regulator (CFTR) is present throughout the pulmonary epithelium of foetal human lung during the first two trimesters [66]. The presence of CFTR has been further demonstrated in cultures of human foetal alveolar epithelial cells on the cell apical surface. Secretion of $\mathrm{Cl}^{-}$by the cultured cells was stimulated by raising intracellular cAMP in the presence of amiloride, an inhibitor of $\mathrm{Na}^{+}$ absorption, indicating that CFTR was active [67].

The importance of sufficient quantities of active surfactant for normal pulmonary function in the neonate is well-established. Analysis of the surfactant-associated proteins in foetal rat and human lungs has raised the possibility that SP-A may have functions in the foetal lung in addition to being a constituent of surfactant. SP$\mathrm{A}$ is only a minor component of the total protein content of lamellar bodies, and the secretion of SP-A is largely independent of the release of lamellar bodies and is constitutive, not responding to secretogogues for lamellar bodies [68]. Moreover, in the ductal foetal rat lung, SP$\mathrm{A}$ is expressed throughout the respiratory epithelium. This is in contrast to surfactant protein-B and C (SP-B and SP-C) which are limited to the distal, prealveolar areas of the ductal system [69]. These observations suggest that SP-A may have functions dissociated from surfactant. Such functions might include the immunomodulatory properties suggested for the molecule in postnatal lungs (see below).

\section{Host defence functions specific to the pulmonary epithelium}

On a daily basis, a person inhales approximately 10,000 $l$ of air. The nose and upper airway act to filter large particulates, and warm and humidify the inspired air. However, the lower respiratory tract is exposed to large amounts of environmental agents on a daily basis. These agents take several physical forms, particulates, gases, fumes, droplets, or biological matter. In addition, it is felt that some degree of aspiration normally occurs during sleep, further exposing the airways to infectious organisms and noxious physical agents. The pulmonary epithelium has several functions, which act to protect the airspaces and preserve normal respiratory function. These functions can be grouped into three categories: 1) features of the epithelium that contribute to the barrier function of the epithelium and the resulting physiological consequences; 2) the co-ordinated interactions of secretion and ciliary function, leading to effective mucociliary clearance; and 3) secretion of substances, both derived from cells other than pulmonary epithelial cells and synthesized by pulmonary epithelial cells, which target specific environmental challenges to the pulmonary epithelial surface. Integration of all these functions is required to maintain a healthy epithelium. Pulmonary diseases associated with disruption of any of these activities quickly leads to the alteration of others and to impairment in pulmonary function.

\section{Barrier function}

The pulmonary epithelium provides a morphological and functional barrier to the environment. Histological studies demonstrate the presence of junctional complexes within the airway and alveolar epithelia [2, 70]. Junctional complexes are composed of three parts: the zonula adherens, desmosomes, and tight junctions [71]. Each of these is believed to have a unique role in the maintenance of epithelial cell interactions. The zonula adherens contains cellular adhesion molecules (CAMs), and contributes to cellular adhesion and recognition. Desmosomes contain a number of proteins, and play a role in epithelial integrity. Finally, the tight junctions, which also are composed of specific proteins, provide a physical barrier function.

The arrangement of the epithelium into a continuous surface by the presence of these junctional complexes leads to important functional consequences. The lumenal cell membrane forms an impermeable barrier to 
macromolecules and infectious agents. Moreover, ionic diffusion is greatly limited by the junctional complexes. Airway epithelial cells are polarized by virtue of having an apical surface (lumenal to the level of the tight junctions) and a basolateral surface (all of the cell membrane basal to the tight junctions). Thus, ion, and, consequently, water transportation, which are crucial for maintaining the proper state of hydration of the fluid which bathes the cilia, can occur in a directed manner [72]. Similarly, epithelial cell products can be transported either to the lumenal surface to interact with environmental agents or basally to affect neighbouring or distant cells.

Exclusion of inhaled particulates and molecules from the basal surface of the epithelium, isolates the exposures, protecting cells underlying the epithelium, which are sensitive to environmental agents. The airway submucosa is rich in a neural plexus which, when stimulated by exposure to irritants, mediates the release of mediators which are associated with airway hyperresponsiveness and airway obstruction [73]. Similarly, resident mast cells are stimulated to release the contents of their secretory granules by a wide range of environmental triggers. Mast cell secretory granules contain a large number of bioactive substances, including histamine and proteolytic enzymes, which may exert deleterious effects upon airway function [74]. The airway mucosal barrier function also serves to lessen the exposure of lymphocytes to potential allergens. The importance of the barrier property for epithelial integrity is illustrated by the experimental observation that cultured airway epithelial cells, grown to confluence and having formed tight junctions, are resistant to the effects of human neutrophil elastase on the epithelial surface [75]. In contrast, the same concentrations of elastase cause detachment of epithelial cells which do not have functional tight junctions [75].

Additionally, the airway epithelium provides an effective barrier against invasion by microbes [76]. The importance of the exclusion of microbes by the epithelium is underscored by the pathogenic importance of the attachment of microbes to the epithelium. This is believed to be the initiating event for infections of the lower respiratory tract. Very few bacterial species have developed mechanisms for attachment to normal, intact human respiratory epithelium, notable exceptions being $M y c o-$ plasma pneumoniae and Bordetella pertussis [77, 78]. However, disruption of the epithelial surface compromises the epithelium, through proliferation of differentiating cells and denudement of extracellular matrix, allowing bacterial attachment to occur [79]. Injury of the airway epithelium by infection with viruses, particularly Influenza virus, permits bacterial attachment [79], and is associated with greatly increased incidence of pneumonia [80]. Clinically, bacterial colonization follows disruption of the normal mucosa, such as results from mechanical injury following endotracheal intubation, or due to squamous metaplasia found in chronic bronchitis. In addition to compromising mucociliary clearance (see below), these changes permit adherence of species of bacteria to the airway mucosa which are usually excluded, e.g. Haemophilus influenza, Streptococcus pneumoniae, and
Staphylococcus aureus [76]. In chronic bronchitis, bacteria colonizing the tracheobronchial tree are associated with exacerbations of airway disease [81].

In the alveoli, accumulation of oedema quickly leads to impairment of gaseous exchange. Alveolar epithelial cell tight junctions are an important barrier to the ingress of interstitial fluid into the airspace.

\section{Mucociliary clearance}

Efficient clearance of inhaled or aspirated particles, including viruses and bacteria, which impact upon the airways, depends upon trapping of the particle in mucus and clearance of the mucus by cough and ciliary activity. As noted above, cilia are not found in the more distal airways. At this level of the airways, particles are cleared by macrophages and cough. Surfactant, produced by Type II epithelial cells and Clara cells, assists in the clearance of particles by coughing, and by changing the surface charge properties, rendering foreign particles "less sticky" and, thus, more easily cleared.

In the more proximal airways, ciliated cells predominate and function to transport airway secretions to the oropharynx, where they can be expectorated or swallowed. The relative importance of cough and mucociliary clearance for the clearance of secretions is not well-defined. Clearly, cough alone is able to remove large amounts of sputum from the lower respiratory tract. However, the importance of mucociliary clearance is demonstrated by the obstructive airway disease, which may result from primary ciliary dyskinesia [82].

The gel phase of respiratory mucus is rich in mucins, which impart to the gel phase the stickiness to trap particulates and the viscoelastic properties characteristic of mucus. Mucins are a group of molecules which consist of high molecular weight $\left(>10^{3} \mathrm{kDa}\right)$, complex glycoproteins. The physiochemical properties of the mucins make them sticky, and thus effective for trapping particulates. In addition to nonspecific interactions, mucins present a great number of potential carbohydrate receptors for more specific interactions [83]. A number of species of bacteria, notably $H$. influenza, S. pneumoniae, and $S$. aureus, bind avidly to airway mucins [76]. Whilst this may be important as a virulence factor for these species, allowing them a "foothold" in the airway, in the presence of normal mucociliary clearance such an interaction would effectively trap the organisms in the airway mucus and contribute to their clearance. The viscoelastic properties of mucus imparted by the mucins, which determine the ease or difficulty for clearance of airway secretions, are altered by infection and airway inflammation.

The distribution of mucus along the airway surface has been a matter of controversy. Experimental evidence suggests that mucus is distributed as discontinuous globules, which become increasingly confluent in the larger airways, resulting in a nearly continuous film of mucus in the large bronchi and trachea [84]. This distribution would help prevent pooling of secretions as they move up the airways, through airways progressively larger in diameter, but smaller in total surface area. 
Table 1. - Factors that alter mucociliary function

\begin{tabular}{lccc}
\hline Factor & $\begin{array}{c}\text { Ciliary } \\
\text { motility }\end{array}$ & $\begin{array}{c}\text { Mucus } \\
\text { velocity }\end{array}$ & Source \\
\hline $\begin{array}{l}\text { B-agonists } \\
\text { Bradykinin }\end{array}$ & $\uparrow$ & $\uparrow$ & Hormonal \\
Histamine & $\uparrow \uparrow$ & $\uparrow$ & Airway neurones \\
& \pm & $\uparrow$ & Eosinophils, \\
Interleukin-1 $\beta$ & $\uparrow$ & $?$ & Mast cells \\
Leukotrienes & \pm & $?$ & Eosinophils \\
Major basophilic protein & $\downarrow$ & $?$ & Eosinophils \\
Nitric oxide & $\uparrow$ & $?$ & Airway epithelium \\
Oxidants & $\downarrow$ & $\uparrow$ & PMNs \\
& & & Macrophages \\
Substance P & $\uparrow$ & $\uparrow$ & Airway neurones \\
Tumour necrosis factor- $\alpha$ & $\uparrow$ & $?$ & Macrophages \\
\hline
\end{tabular}

PMN: polymorphonuclear cells.

\section{Interactions of ciliated epithelial cells and inflammatory cells}

Effective mucociliary clearance is dependent on the propulsion of airway mucus by the co-ordinated beating of cilia. The regulation of ciliary motility and mucociliary clearance is complex and not completely understood. However, it is clear that immune effector cells and their products play an important role in altering and regulating mucociliary function (table 1 ).

Activated polymorphonuclear cells (PMNs) are capable of releasing oxidants, including hydrogen peroxide and superoxide [85], which have been demonstrated to impair ciliary function [86], and which may decrease ciliary motility in conditions associated with airway neutrophilia, e.g. chronic bronchitis [87]. Neutrophils can release a number of proteases, such as elastase, which probably damage ciliated cells, and have been shown to arrest mucociliary activity [88]. PMNs can also produce bioactive lipids, such as platelet-activating factor [89], which may impair ciliary motility and decrease mucociliary clearance [90].

Macrophages can synthesize a variety of inflammatory products that have been shown to alter ciliary motility. Macrophages, like PMNs, produce cilia-damaging oxidants and proteases. In contrast to their ability to release factors that impair ciliary functions, macrophages also have a robust capacity to synthesize cytokines, which appear to upregulate mucociliary function. Tumour necrosis factor- $\alpha$ (TNF- $\alpha$ ) and interleukin-1 $\beta$ (IL-1 $\beta$ ), released from alveolar macrophages, have recently been shown to upregulate ciliary beat frequency related to the release of nitric oxide (NO) in a manner that requires induction of NO synthase (NOS), and is blocked by glucocorticoids [91]. Neural and hormonal mediators, such as $\beta$-agonists [92-95], bradykinin [92, 96-98], and substance P $[99,100]$, which upregulate ciliary beat frequency, also effect NO synthesis. However, in contrast to the response to cytokines, the NO-dependent increase in ciliary beat frequency is rapid and transient. The difference in the temporal response of ciliary motility to NO in these differing circumstances suggests that $\mathrm{NO}$ is a fundamental cellular signal for upregulating ciliary motility, regardless of how it is triggered. The rapid transient increase in ciliary motility is likely to occur during "fight or flight" conditions, such as during exercise, whereas the release of the cytokines during macrophage activation may by an important mechanism by which mucociliary clearance is increased during infection, allergies, or other sustained inflammatory conditions.

Eosinophils are laden with substances which, when released, may impact on ciliary motility. Major basophilic protein, which is released from injured eosinophils, is known to impair ciliary motility [101], and probably accounts for the damage that occurs to nasal ciliated cells co-cultured with eosinophils [102]. Interestingly, this effect can be attenuated by adding nedocromil sodium. This suggests that the ciliastasis is a consequence of the inflammatory response. Histamine and leukotrienes, inflammatory mediators released from basophils, mast cells, and platelets during anaphylaxis, can have variable effects on ciliary motility [103]. For example, inhalation of histamine increases tracheal mucus velocity in human volunteers [104], but has no effect on ciliary motility in vitro [105].

Activated lymphocytes can alter ciliary activity. Activated lymphocytes are a rich source of cytokines, such as $\gamma$-interferon, which can induce NOS in epithelial cells [106]. It is also likely that other lymphocyte-derived cytokines impact on ciliary motility in the airway, especially in conditions associated with chronic inflammation, such as asthma and bronchiolitis.

Thus, the cells and mediators of the immune system can both impair and enhance mucociliary function, impacting upon lung host defences. It is clear that the complex regulation of these cells and release of their mediators is required to maintain normal function. Loss of balance in effector signals leads to injury of this vital host defence function.

\section{Epithelial cell mucous secretions}

In addition to providing the mucins integral for trapping particulates and normal mucociliary clearance, the airway epithelium secretes a number of substances with a variety of properties important for host defence of the airways. Airway secretions provide protection against a wide variety of potentially injurious agents, including infection, reactive oxygen species and proteases (table 2).

\section{Antimicrobial activities}

The lower respiratory tract is protected against infection by complimentary mechanisms. In addition to the exclusion of microbes by the airway epithelial barrier function, trapping by mucins, and clearance by the mucociliary escalator and cough, the airway epithelium secretes a number of substances with antimicrobial properties [107]. Some of these substances have direct antibacterial activities, such as lysozyme [108], and 
Table 2. - Pulmonary epithelial cell-derived substances and host defence

Mucins
Antibiotic Substances
SP-A
Immunoglobulin A
Complement
Lactoferrin
Lysozyme
Antioxidants
SP-A
Lactoferrin
Glutathione
Catalase
Antiproteases
Elafin
Secretory leukoprotease
CC10

SP-A: surfactant-associated protein A.

lactoferrin [109-110]. Others, especially components of the complement system [112], and perhaps SP-A [113, $114]$, act as opsonins, allowing for efficient phagocytosis. Secretory immunoglobulin A ( $\mathrm{sIgA}$ ) plays a major role in airway host defence, as demonstrated by the susceptibility to infection which may result from $\operatorname{sigA}$ deficiency [115]. Plasma cell-derived IgA is specifically bound by the epithelial cell basal-surface receptor, secretory component. The complex is transported from the basolateral cell surface to the apical surface, where it is secreted [116]. Secretory IgA acts primarily upon viruses, but on bacteria also, coating them and preventing attachment to the respiratory epithelium [117].

Lactoferrin is a major secretory product of the mucous gland serous cells, which has modest direct bacteriostatic properties, but which is presumably more effective as a sink for iron [118]. When bound to lactoferrin, and the closely related serum protein transferrin, iron is made unavailable to most bacterial species, depriving them of this essential growth factor. These epithelial cell products interact with antimicrobial substances from other cell sources, such as defensins from neutrophils, and immunoglobulin $\mathrm{G}(\mathrm{IgG})$, which are also present in airway secretions, together forming an effective array of antimicrobial defences.

\section{Antioxidant activities}

The airway epithelium is constantly exposed to an oxidant-rich environment. Cigarette smoke [119] and other inhaled exposures such as ozone and $\mathrm{NO}_{2}$ [120], as well as activation of inflammatory cells [121-123] increases the oxidant burden to which the airway epithelial cells are exposed. Reactive oxidant species are potent initiators of cell injury, and oxidant-mediated cell injury has been identified in a growing number of pulmonary diseases [124]. Airway epithelial cells have both intracellular and extracellular antioxidant activities.

Airway epithelial cells share with other lung cells three major intracellular antioxidant systems, the glutathione redox cycle, superoxide dismutase, and catalase [124].
Superoxide dismutase reduces the superoxide radical to $\mathrm{H}_{2} \mathrm{O}_{2}$ and catalase reduces $\mathrm{H}_{2} \mathrm{O}_{2}$ to water. The glutathione redox system maintains a high ratio of reduced glutathione (GSH)/oxidised glutathione (GSSG). Reduced GSH reduces intracellular hydroperoxides, lipid peroxides, and products of lipoxygenase-catalysed reactions. The high intracellular concentrations of GSH and its ubiquitous distribution within the cell, suggest that the GSH redox cycle is of central importance. Exposure of epithelial cells to oxidant stress leads to upregulation of intracellular antioxidant mechanisms [124].

The extracellular epithelial lining fluid is rich in antioxidant activities. Much of the antioxidant activity of the epithelial lining fluid is derived from the serum. However, epithelial cells release substances with specific antioxidant activities. Prominent amongst these is lactoferrin, which is synthesized and secreted by serous cells. Together with serum-derived transferrin and ferritin, lactoferrin avidly binds iron as $\mathrm{Fe}^{3+}$. Lactoferrin and transferrin, and under most conditions ferritin, bind iron in a manner which renders the iron inaccessible for the catalysis of the Haber-Weiss reaction. In this reaction, iron, as $\mathrm{Fe}^{2+}$, is rate-limiting for the formation of hydroxyl or hydroxyl-like radicals, which are potent initiators of oxidant chain reactions. Whilst both lactoferrin and transferrin, unlike ferritin, are resistant to oxidant-induced release of bound iron $[125,126]$, transferrin releases its bound iron at a $\mathrm{pH}$ less than 5 . In contrast, lactoferrin is resistant to this effect of acidic environments [127], a property important on mucosal surfaces, where local effects of inflammation may lower the $\mathrm{pH}$. Recent data suggest a role for SP-A as an antioxidant in the lower respiratory tract. SP-A, in physiologically relevant concentrations, has been found to inhibit superoxide production by alveolar macrophages stimulated by phorbol 12-myristate-13-acetate (PMA) or zymosan-activated serum [128]. Primarily intracellular antioxidants, e.g. catalase and glutathione, are presumably released from airway epithelial cells and contribute to the antioxidant activity of the epithelial lining fluid [129, 130].

The antioxidant activity of lower respiratory tract epithelial lining fluid has been measured and partially characterized [131]. Deficiencies have been found in association with smoking cigarettes [132]. Moreover, cigarette smoking has been shown to be associated with the presence of abnormal, oxidized substances in the epithelial lining fluid [133]. These observations would suggest that exposure to cigarette smoke may overwhelm airway antioxidant defences, and that oxidants may contribute to airway inflammation in chronic bronchitis.

\section{Antiprotease activities}

Pulmonary inflammatory cells, including neutrophils, macrophages, basophils and mast cells, are rich sources of proteases. Activated inflammatory cells release their proteases extracellularly, causing the concentrations of proteases to become quite high in the local surroundings of the activated cells [134]. Cleavage of pulmonary parenchymal proteins by proteases and direct effects on airway epithelial cells have been postulated to be 
important pathogenic mechanisms for both emphysema and chronic bronchitis. Normally, the airway epithelium and lung parenchyma are protected from the effects of proteases by the presence of an excess of antiproteases.

The pulmonary antiproteases are largely class specific. Thus, $\alpha_{1}$-protease inhibitor, secretory leucoprotease inhibitor (SLPI), and $\alpha_{1}$-antichymotrypsin are inhibitors of serine proteases, especially neutrophil elastase, and tissue inhibitors of metalloproteases (TIMP) inhibit metalloproteases. In contrast, $\alpha_{1}$-macroglobulin is not class specific, and inhibits proteases from all four of the protease classes, serine, metallo-, cysteine and aspartic, whilst elafin is specific for elastase The lower respiratory tract antiproteases are derived from a variety of sources, including the serum $\left(\alpha_{1}\right.$-protease inhibitor, $\alpha_{1}$-antichymotrypsin, and $\alpha_{1}$-macroglobulin) and pulmonary macrophages ( $\alpha_{1}$-protease inhibitor and $\alpha_{1}$-macroglobulin). The source of elafin in the lower respiratory tract has not been entirely determined, but it appears to be derived from pulmonary epithelial cells. The Clara cell-like cell line, NCI-H322, and the Type II cell line A549, both secrete elafin [135].

Likewise, SLPI derives entirely from the pulmonary epithelium. It has been presumed to be a predominant inhibitor of neutrophil elastase in the airways, and also inhibits other serine proteases, including mast cell chymase, cathepsin G, trypsin, chymotrypsin. It is derived from glandular serous cells as well as the surface epithelium in the central airways, from Clara cells in the more distal airways, and from Type II cells in the alveoli [135-138]. Furthermore, it is elevated in states of airway inflammation, suggesting upregulation of synthesis [139]. However, the precise role of SLPI is clouded by the observation that the majority of SLPI recovered from the airways of normal individuals is inactivated [140]. The inactivated SLPI is not bound to human neutrophil elastase, nor has it been cleaved into smaller peptides. SLPI is sensitive to oxidative damage by neutrophil products, and, thus, inactivation of SLPI in situ could result from interaction with resident neutrophils. SLPI could still play a significant role in the airway, as its release from epithelial cells directly subjacent to neutrophils might result in high, local concentrations, and act as a first line of defence against neutrophil elastase.

Imbalance of lung proteases and antiproteases, favouring increased free protease burden has been documented in inflammatory lung diseases, especially those associated with an influx of neutrophils into the lung. Free neutrophil elastase is not normally measurable in the epithelial lining fluid. However, free neutrophil elastase can be found in some cigarette smokers [141]. In animal studies, the instillation of free elastase into the airways leads to emphysema and goblet cell hyperplasia, suggesting that free proteases may contribute to the morphological changes found in the airway in patients with chronic bronchitis [142]. Proteases have also been demonstrated to be potent secretogogues for airway epithelial cells [143]. Thus, proteases potentially contribute to the hypersecretory state which characterizes chronic airway inflammation via both morphological and functional mechanisms.

\section{Regulation of cellular activities}

Airway epithelial cells, in addition to having the functions important for host defence, which are described above, participate in the regulation of other airway cells contributing to the host response to environmental stresses. Cells with which pulmonary epithelial cells have been shown to interact include the following: 1) inflammatory cells, important for host defence, but associated with injury if unchecked; 2) airway and bronchial vascular smooth muscle cells, cells which are intrinsic to the airway and vital for airway function; and 3) airway mesenchymal cells, which play a major role in the reparative response to injury. Presumably, these mechanisms, by providing an interface between inhaled environmental constituents and the lung, are important for maintaining normal airway function. However, evidence suggests that in pathological states, stimulation of pulmonary epithelial cells can contribute to disordered lung function.

\section{Inflammatory cells}

There is much experimental evidence to suggest that airway epithelial cells interact with inflammatory cells via a number of mechanisms (summarized in fig. 1). Airway epithelial cells have the capacity to recruit inflammatory cells to the airways via the release of chemoattractants, to direct inflammatory cell migration across the epithelium via the expression of cell surface molecules, and to regulate inflammatory cell activity via the release of cytokines. Each one of these steps amplifies the inflammatory response, establishing the importance of airway

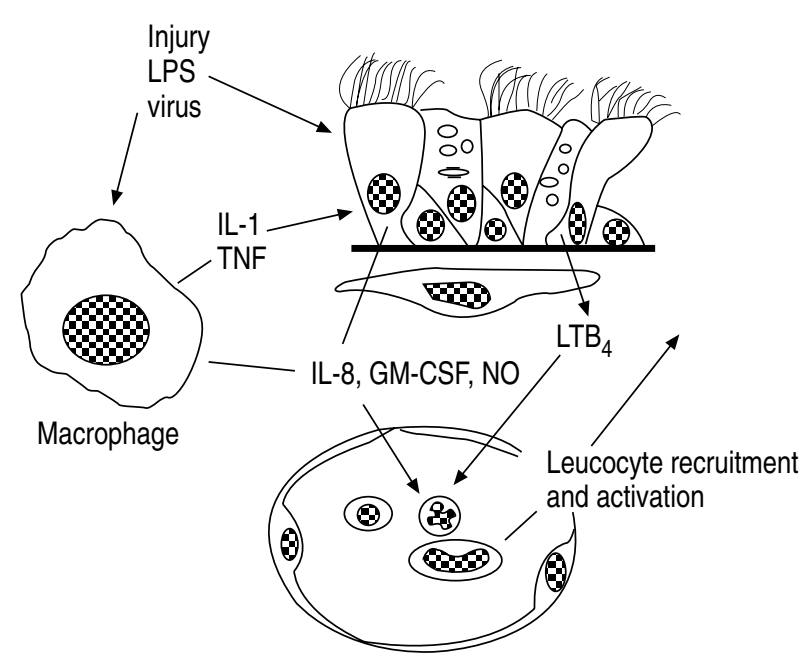

Fig. 1. - Cytokine interactions between airway epithelial cells and inflammatory cells. Inflammatory stimuli, e.g. LPS or viral infection, intitiate release of mediators including $\mathrm{LTB}_{4}, \mathrm{IL}-8$, NO, and GM-CSF from epithelial cells, and IL-1 and TNF from macrophages, which further stimulate the epithelial cells. The macrophages and epithelial cells augment the inflammatory response by releasing additional mediators that recruit and activate leucocytes. LPS: lipopolysaccharide; $\mathrm{LTB}_{4}$ : leukotriene $\mathrm{B}_{4}$; IL-8: interleukin-8; NO: nitric oxide; GM-CSF: granulocytemacrophage colony-stimulating factor; IL-1: interleukin-1; TNF: tumour necrosis factor. 
epithelial cells for the modulation of airway inflammatory diseases. Recently, evidence has accrued to suggest that alveolar epithelial cells may also interact with inflammatory cells.

\section{Recruitment of inflammatory cells}

Cultured airway epithelial cells, under basal conditions, release negligible amounts of neutrophil chemotactic activity, but respond to a number of stimuli by upmodulating this activity [144]. Stimuli shown to enhance the release of neutrophil chemotactic activity, in vitro, include environmentally-derived stimuli, cigarette smoke extract [145], endotoxin [146], organic dust extract [147], and viruses [148], stimuli derived from cells intrinsic to the lungs, cytokines, substance P, neutrophil proteases, and acetylcholine, and other experimentally important stimuli, calcium ionophore, phorbol myristate acetate, and opsonized zymosan [149]. In vitro observations have been confirmed in vivo using bronchoalveolar lavage, which have demonstrated low basal activity with significant increases of neutrophil chemotactic activities in states of airway inflammation [150].

Whilst many exposures lead to upregulation of the release of neutrophil chemotactic activity, the regulation of release of neutrophil chemotactic activity is complex and involves opposing pathways with stimulatory and inhibitory activities [151]. Increases of intracellular cAMP are associated with attenuation of release of neutrophil chemotactic activity [152]. Thus, substances which are known to stimulate intracellular cAMP levels for which there are airway epithelial cell receptors, such as $\beta$-agonists and vasoactive intestinal peptide, are potential downregulators of chemotactic activity release.

The identity of the neutrophil chemotactic activities and the time course of release following stimulation of the epithelial cell has been partially established. Within the first few hours after smoke or lipopolysaccharide (LPS) stimulation, bronchial epithelial cells release arachidonic metabolites. Whilst species differences are likely, leukotriene $\mathrm{B}_{4}\left(\mathrm{LTB}_{4}\right)$ and hydroxyeicosatetraenoic acids (HETEs) with neutrophil chemotactic activity have been reported [146, 153-155]. Although in vivo proof is lacking, it has been suggested that this early release of $\mathrm{LTB}_{4}$ accounts for the initial attraction of neutrophils into the lower respiratory tract. Subsequent to the initial response of the epithelial cells to a provocative stimulus, macrophage stimulation of epithelial cells by TNF or IL-1 is thought to perpetuate the inflammatory response by the release of chemokines.

Chemokines are low molecular weight peptides, which belong to a superfamily consisting of a number of structurally related cytokines characterized by conservation of a four cysteine motif (table 3) [156]. The chemokine superfamily can be divided into two branches, according to the position of the first two cysteines. The $\mathrm{C}-\mathrm{X}-\mathrm{C}$ branch, where the first two cysteines are separated by an intervening residue, includes such chemokines as interleukin-8 (IL-8), platelet factor-4 (PF-4), neutrophilactivating peptide-2 (NAP-2), neutrophil-activating protein from epithelial cells (ENA-78), and melanocyte
Table 3. - The chemokines

\begin{tabular}{lcl}
\hline & C-X-C Subfamily & C-C Subfamily \\
\hline Target cells & Neutrophils & Monocytes \\
Major members & IL-8 & MCP-1 \\
& PF-4 & MIP-1 $\alpha$ \\
& NAP-2 & MIP-1 $\beta$ \\
$\begin{array}{l}\text { Known airway epithelial } \\
\text { cell product }\end{array}$ & IL-8 & RANTES \\
\hline
\end{tabular}

IL-8: interleukin-8; PF-4: platelet factor-4; NAP-2: neutrophilactivating peptide-2; MCP-1: monocyte chemotactic protein-1; MIP- $1 \alpha$ and $\beta$ : macrophage inflammatory protein- $1 \alpha$ and $\beta$; RANTES: regulated on activation, normal T-cells, expressed and secreted.

growth-stimulatory activity. In general, the $\mathrm{C}-\mathrm{X}-\mathrm{C}$ branch of chemokines preferentially attract neutrophils. The other branch of the chemokine superfamily, the C-C branch, where the first two cysteines are not separated by an intervening residue, includes RANTES (regulated upon activation in normal T-cells expressed and secreted), human monocyte chemotactic protein-1 (MCP-1), macrophage inflammatory proteins- $1 \alpha$ and $-1 \beta$ (MIP-1 $\alpha$ and $-1 \beta)$. The $\mathrm{C}-\mathrm{C}$ branch of chemokines preferentially attract monocytes, although several members of both branches of the chemokine superfamily have cell specific chemotactic properties (discussed below).

In the context of the lower respiratory tract, there is abundant evidence that airway epithelial cells can be induced to release IL-8, one of the most potent chemotactic factors for neutrophils [148, 157-159]. Although not demonstrated at the time of this writing, it seems likely that other members of the $\mathrm{C}-\mathrm{X}-\mathrm{C}$ branch might also be released by lung epithelial cells. The release of IL- 8 by cultured human lung epithelial cells in response to TNF is directionally specific, suggesting that the epithelial cells can direct inflammatory responses to either their basal or apical surface [160]. Corticosteroids are potent inhibitors of IL- 8 mRNA transcription, suggesting that airway epithelial cells are a rational target for the therapy of airway inflammatory disorders [158].

The lung macrophage is largely derived from the peripheral blood monocyte [161]. Release of monocyte chemotactic activity by stimulated bronchial epithelial cells has been demonstrated, and is similar in many respects to the stimulated release of neutrophil chemotactic activity [146, 155]. This is not unexpected, since it is often observed clinically that increased numbers of macrophages and neutrophils may coincide in the lower respiratory tract during chronic inflammation. Furthermore, $\mathrm{LTB}_{4}$ and some of the chemokines are chemotactic for both monocytes and neutrophils [157]. In particular, RANTES has been identified as a product of cultures of the human lung epithelial cell line, A549. Following stimulation with TNF or IL-1, RANTES peptide is found in the supernatant fluid in association with increases in mRNA [162]. This suggests that RANTES may, at least in part, be responsible for the monocyte chemotactic activity derived from lung epithelial cells. It seems likely that other $\mathrm{C}-\mathrm{C}$ chemokines might be induced in lung epithelial cells. 
Airway epithelial cells have several potential mechanisms for the recruitment of eosinophils. RANTES and $\mathrm{LTB}_{4}$ are both eosinophil chemoattractants [163, 164]. Airway epithelial cells have also been demonstrated to release platelet-activating factor [165], a potent eosinophil chemoattractant [166].

Chemotactic activity for lymphocytes is also released by airway epithelial cells, and has been suggested to account for the presence of lymphocytes in the airway mucosa and bronchial associated lymphoid tissue (BALT) [167]. Separation of bronchial epithelial cell-derived lymphocyte activity on molecular sieve column chromatography reveals several peaks of chemotactic activity which are remarkably similar to results obtained from keratinocytes [167, 168]. Identification of the exact nature of these lymphocyte chemotactic factors is unknown, but RANTES is a chemoattractant for CD4+ lymphocytes [156], and corresponds in molecular weight and lymphocyte specificity to one of the peaks of chemotactic activity released by bronchial epithelial cells [156, 167].

\section{Cell-cell adhesion molecules}

A number of recent investigations have demonstrated the importance of intercellular adhesion molecule-1 (ICAM-1) expression by lung epithelial cells. ICAM-1 is the ligand for the CD11/CD18 leucocyte integrins expressed on the surface of neutrophils, monocytes, lymphocytes, and eosinophils [169, 170]. Cell-cell contact mediated by leucocyte integrin/ICAM-1 interaction is thought to be important in inflammatory cell-induced target recognition and cytotoxicity [171]. Thus, leucocyte integrin/ICAM-1 interactions may play important roles in leucocyte adhesion to epithelial cells, followed by maturation and activation of leucocytes in the epithelial compartment. Cytokines, such as TNF, IL-1 and $\gamma-$ interferon $(\gamma$-IFN) appear to contribute to epithelial cell and inflammatory cell interactions by enhancing ICAM1 expression on epithelial cells [172].

The potential therapeutic implications of the central role of ICAM-1 in airways inflammation have been documented in a primate model of asthma [173]. In these experiments, infiltration of eosinophils into the airway was correlated with epithelial cell expression of ICAM-1. Intravenous administration of anti-ICAM-1 antibodies attenuated both airway eosinophilia as well as bronchial hyperresponsiveness. In human tissue, ICAM1 receptors have recently been identified on bronchial epithelial cells from asthmatics, but not from nonasthmatics [174]. Whilst not segregating the role of endothelial cells and epithelial cells, these results provide strong support for the role of ICAM-1 in the recruitment and maintenance of airway eosinophilia in association with asthma.

Alveolar epithelial cells have recently been demonstrated to express ICAM-1. In one set of experiments, freshly isolated rat Type II cells did not exhibit ICAM1 by immunofluorescence. With continuing culture, ICAM-1 was present in low levels after $24 \mathrm{~h}$, and in abundance after $48 \mathrm{~h}$, as the cells developed a Type I cell phenotype [175]. This suggested that ICAM-1 expression in the alveolar epithelium is a function of Type I cells, an assertion confirmed by immunofluorescence in frozen sections of normal lung. The cultured cells exhibited ICAM- 1 activity as the ICAM- 1 specific monoclonal antibody, MoAb 1A29, blocked adherence of activated T-lymphocytes to the epithelial cells.

These findings were confirmed in a mouse model of hyperbaric lung injury. Using immunocytochemistry and electron-microscopy, it was demonstrated that in normal lungs ICAM-1 expression was limited to Type I cells and tended to be concentrated around cell junctions [176]. With exposure to hyperoxic conditions, the distribution of ICAM-1 on Type I cells changed, becoming more homogeneous on the apical epithelial surface, and Type II cells expressed large amounts of ICAM-1 on their surface. The ability of human Type II cells to express ICAM-1 has been confirmed by immunocytochemical characterization of Type II cells freshly isolated from histologically normal sections of lung removed during resection for lung cancer [177]. Thus, the expression of ICAM-1 by alveolar epithelial cells is responsive to phlogisitic stimuli, and may direct inflammatory cell recruitment and retention in the alveoli.

Pulmonary epithelial cells are capable of expressing major histocompatibility complex (MHC) antigens [178-181]. Expression of MHC antigens allows cells to directly interact with T-lymphocytes, and makes them potential targets for cytotoxic T-cells and candidates for antigen presentation to helper T-cells. The expression of MHC class II antigens (human leucocyte antigen (HLA)-DR, DQ and DP) is relatively low in normal airway epithelium, but can be increased under certain conditions. In cultured epithelial cells, the most potent stimulation for MHC class II expression appears to be $\gamma$-IFN [179, 180], and TNF may potentiate $\gamma$-IFN effects [180]. Bronchial epithelial cells that express MHC class II antigens are capable of stimulating allogenic lymphocyte reactions [179]. HLA-DR antigens have been identified on freshly isolated human Type II cells [181], raising the possibility that alveolar epithelium may likewise contribute to the stimulation of lymphocytes.

The presence of MHC antigens on epithelial cells is thought to be important for the pathogenesis of airway disease that occurs after lung transplantation [182, 183]. Similar to the aberrant MHC antigen expression described in rejection of other organs, increased MHC expression on epithelial cells in transplanted lungs is probably responsible for immune rejection resulting in obliterative bronchiolitis [183]. A parallel phenomenon probably occurs during the obstructive airways disease that occurs in relation to graft versus host disease after allogenic bone marrow transplantation [184].

The ability to express MHC class II antigens raises the possibility that airway epithelial cells are capable of directly presenting soluble antigens to helper T-cells [185, 186]. Whilst bronchial epithelial cells are capable of stimulating allogenic lymphocyte reactions, they appear to be poor at processing and presenting soluble antigens. Enterocytes from the gut have been demonstrated to be 
capable of presenting selected antigens, and keratinocytes are capable of presenting some super antigens [187-190]. Thus, whilst direct experimental evidence for antigen presentation by airway epithelial cells is lacking, there remains the possibility that epithelial cells may play a limited role in this regard.

\section{Modulation of inflammatory cell activity}

An important aspect of the regulation of lung inflammatory responses is thought to be the modulation of cellular responses by pulmonary epithelial cells. Cytokines, which are chemoattractants for inflammatory cells, also tend to be stimulators of inflammatory cells. Moreover, both airway and alveolar epithelial cell expression of cell-cell adhesion molecules may contribute to the activation of inflammatory cells $[173,175]$. However, certain cytokines may demonstrate both anti- and proinflammatory effects, and epithelial cells may release cytokines with predominantly anti-inflammatory effects. Thus, epithelial cells may produce both the critical proinflammatory or anti-inflammatory activities that control the progress of inflammatory events. These observations have lead to the concept that these structural cells play an important role, contributing to the network of cytokines that control chronic airway inflammation [191]. Investigation of the components of this cytokine network have lead to a recognition of complex intracellular interactions between epithelial cells and inflammatory cells.

Many of the chemotactic factors released by airway epithelial cells have also been demonstrated to activate neutrophils, monocytes (or macrophages), eosinophils and lymphocytes. However, as pointed out by MARTIN et al. [192], in vitro studies do not always correctly predict in vivo results. $\mathrm{LTB}_{4}$ is known to cause neutrophil degranulation and superoxide production in vitro [193]. $\mathrm{LTB}_{4}$ induced the expected neutrophil accumulation when instilled into the lungs of normal volunteers. However, the anticipated increase in protein and markers of neutrophil activation in bronchoalveolar lavage fluid did not occur. These results have been interpreted to suggest that neutrophil activation in vivo may be more complex than previously thought, requiring more than one stimulus, with specific concentration or time dependencies.

Recent investigations demonstrate that the presence of inflammatory cells within tissues might not be entirely attributable to the continual attraction of these cells from the vasculature, but also by inhibition of programmed cell death (apoptosis) [194], and epithelial cell-directed maturation of inflammatory cells. Studies with conditioned medium from cultures of human bronchial epithelial cells markedly enhanced the survival of neutrophils, macrophages and eosinophils [195-197]. The survivalenhancing properties of the conditioned media have been attributed to epithelial cell release of granulocyte-macrophage colony-stimulating factor (CSF), granulocyte-CSF or macrophage-CSF alone or in combination [195-197]. The release of growth factors from epithelial cells can also induce monocytic [198], and mast cell [199] differentiation. GM-CSF release is responsive to IL-1 [200], suggesting a mechanism for upregulation in airway inflammation.

The search for the identification of the endothelialderived relaxing factor led to the appreciation of $\mathrm{NO}$ as a pulmonary vasodilatory agent [201]. However, it has also become apparent that NO may have a number of other effects in the lung in addition to smooth muscle relaxation, including neurotransmission, cytotoxicity for micro-organisms and tumour cells, alteration of enzyme activities, and modulation of ciliary beat frequency (reviewed above) [202]. NO has also been demonstrated to modulate inflammatory cell chemotaxis. In the context of the lower respiratory tract and inflammation, neutrophils, macrophages, and bronchial epithelial cells have all been demonstrated to release NO under stimulated conditions. This suggests that a complex interplay may occur between epithelial cells and inflammatory cells via NO production [202].

In addition to recruiting and stimulating inflammatory cells, epithelial cells may participate in the downregulation of inflammatory cells. Transforming growth factor- $\beta$ (TGF- $\beta$ ) is present in the epithelial lining fluid of the lung, and is present in the epithelium of injured lung [203, 204]. In addition to important effects on matrix production, TGF- $\beta$ has anti-inflammatory properties, such as the inhibition of interleukin-2 (IL-2)-dependent proliferation of T-cells [205]. TGF- $\beta$ also inhibits cytokine production by macrophages [206]. Several cell types in the lung have been shown to produce TGF- $\beta$, including airway epithelial cells [207-209], and macrophages [210].

Other mediators with anti-inflammatory properties produced by airway epithelial cells include prostaglandin $\mathrm{E}_{2}\left(\mathrm{PGE}_{2}\right)$ and interleukin-6 (IL-6). $\mathrm{PGE}_{2}$ has a number of anti-inflammatory effects, including reduction in the production of neutrophil chemoattractants by macrophages [211]. IL-6 is capable of reducing inflammation in several models of inflammation, including an in vivo model of pulmonary inflammation [212]. In the context that IL-6 also has well-documented proinflammatory effects, such cytokines may be "bifunctional", with differing activities depending on the progression of the inflammatory process.

The alveolar epithelium has also been demonstrated to have immunosuppresive activities. Using the Type II cell-like cell line, A549, a protein with T-cell suppressive activities has been identified [213]. With a molecular weight of about $70 \mathrm{kDa}$, the protein was found to arrest T-cell proliferation between $G_{1}$ and $S$ phase. Whilst not fully characterized, the presence of such a protein in the alveolar space would provide the alveolar epithelium with an important defence against unchecked immune responses to inhaled antigens, thereby protecting the close proximation of airspace and blood needed for optimal gas exchange.

Surfactant can modulate inflammatory cell activity, downregulating lymphocyte functions and enhancing macrophage functions. Studies with whole surfactant have demonstrated inhibition of lymphocyte activities, including natural killer activity, proliferation, and immunoglobulin synthesis [214-218]. The lymphocyte 
suppressor activities of surfactant have been isolated to the lipid fraction of surfactant [215], but the mechanisms responsible for the modulation of lymphocyte functions have not been established. In contrast, SP-A is probably responsible for the macrophage enhancing effects of surfactant [219]. SP-A enhances macrophage migration [220], opsonophagocytosis [219, 221, 222], intracellular killing of Staphylococcus aureus [221, 223], and killing of tumour cells [224]. SP-A may alter macrophage activities via a specific receptor [225].

\section{Interactions with parenchymal cells}

Adaptive responses to injury and the repair of epithelium surfaces following injury are essential components of normal immune responses. Experimental evidence suggests that epithelial cells, in addition to interacting with inflammatory cells, interact with pulmonary parenchymal cells. These interactions with smooth muscle cells, endothelial cells, other epithelial cells, and fibroblasts influence airway functions, such as airway tone, vascular permeability, and repair of damaged epithelium.

\section{Smooth muscle cells}

Airway epithelial cells are capable of modulating airway smooth muscle cells and, therefore, smooth muscle tone via several mechanisms including both direct effects and by modulation of known bronchoconstricting and bronchodilating agents. Cultured airway epithelial cells release substances with direct bronchoconstricting properties, such as endothelin [226], and arachidonic acidderived lipoxygenase products [227]. Similarly, bronchial epithelial cells also release substances with direct bronchodilatory effect, including $\mathrm{PGE}_{2}$ [228]. As noted above, the nonprostanoid endothelial-derived relaxing factor [229] has been shown to be primarily NO. Bronchial airway epithelial cells appear to have NOS activity [230]. However, NO does not appear to be responsible for epithelium-derived relaxing factor activity [231].

Airway epithelial cells also influence smooth muscle tone indirectly, by metabolizing agents such as neuropeptides. The membrane of bronchial epithelial cells contain the enzyme neutral endopeptidase (NEP), which degrades the bronchoconstricting neuropeptide substance P [232]. Loss of epithelial cells as a source of NEP in viral infection results in increased substance $\mathrm{P}$-induced bronchoconstriction [233]. Similarly, epithelial cellassociated NEP also modulates the ability of endothelin to induce bronchoconstriction [234].

Thus, airway epithelial cells both release and metabolize substances which modulate airway smooth muscle tone. These activities are regulated by a variety of agents and injury, making the underlying airway responsiveness a balance of multiple interactions. Indirect effects of airway epithelial cells may also have long-term effects on airway smooth muscle. For example, TGF- $\beta$, a product of bronchial epithelial cells, can alter smooth muscle $\beta$ adrenergic receptors [235], and, thereby, alter the response of smooth muscle to $\beta$-agonists.

\section{Endothelial cells}

Epithelial cells have the capability of altering endothelial cell function, contributing to vascular permeability and oedema seen in inflammatory pulmonary diseases. As already noted, bronchial epithelial cells express enzymes, such as neutral endopeptidase (NEP) and angiotensin converting enzyme (ACE), and Type I epithelial cells contain carboxypeptidase $\mathrm{M}$, all enzymes capable of degrading neuropeptides released by sensory nerves in the airway [236, 237]. Thus, pulmonary epithelial cells potentially contribute to the containment of neuropeptides. The balance of active peptides and peptidases in the airway may play a role in the pathogenesis of airway inflammation, in that conditions such as cigarette smoke can both stimulate release of neuropeptides and reduce neutral endopeptidase activity [238]. In addition, agents such as corticosteroids can alter epithelial cell NEP expression [239].

Airway epithelial cells contain a variety of other enzymes, which may contribute to the metabolism of inflammatory mediators involved in airway oedema. In particular, epithelial cells are a source of histamine-degrading enzymes, such as histamine $\mathrm{N}$-methyltransferase, and are, thus, capable of modulating histamine effects on vascular permeability [240]. Arachidonate 15-lipoxygenase is located in tracheal epithelial cells, and may influence the generation of metabolites affecting permeability [241]. NO production by bronchial epithelial cells may also contribute to the modulation of endothelial cell function [242-244]. Thus, epithelial cells, which are often exposed at an early stage to a variety of insults and inflammatory mediators, may play important roles in metabolizing those mediators, and subsequently influencing endothelial cell function.

\section{Epithelial cells}

Interactions between epithelial cells may be of primary importance in directing repair of injury. After airway epithelial damage, epithelial cells at the edge of the injury appear to flatten out and migrate across the provisional matrix of the wound to close the defect [245]. This ability to migrate is probably influenced by several factors, including the constituents of the extracellular matrix [246]. Soon after injury occurs, increased expression of fibronectin (Fn) and tenascin has been demonstrated in wound matrix, whilst changes in laminin and type IV collagen expression appear later [245]. Fn, in particular, is thought to have a significant role in the modulation of epithelial cell migration. Bronchial epithelial cells in vitro demonstrate chemotaxis to Fn using a blindwell chamber technique [247]. Furthermore, bronchial epithelial cells in culture produce chemotactic factor for epithelial cells, which is predominantly Fn [248]. This epithelial cell-derived Fn has been shown to be more potent as a chemotactic factor for airway epithelial cells than plasmaderived Fn [248]. Plasma-derived Fn appears early in a wound [249], but cellular Fn has unique properties that enhance repair [250]. The exact mechanisms by which 
bronchial epithelial cell Fn modulates migration are not yet defined.

Airway epithelial cell Fn may differ from plasma Fn as a consequence of mRNA splicing or post-translational modification of the glycoprotein. Two major regions of the Fn gene are typically involved in mRNA splicing [251]. These include the extra domain regions (EIIIA and EIIIB), which are either totally included or excluded, and the variable or IIICS region, which has several splice donor and acceptor sites within the exon. The expression of splice variants has been shown to be cell and tissue specific [252]. Importantly, WANG et al. [253] have shown that guinea-pig tracheal epithelial cells preferentially express EIIIA containing Fn from the apical surface of cultures. The unique function of EIIIA containing Fn or other splice variants in airway repair has not been elucidated. However, the potential importance of Fn splice variants in disease is supported by the recent observation that the IIICS Fn variant is involved with the synovial inflammatory response of rheumatoid arthritis [254].

The production of matrix molecules, and Fn in particular, can be influenced by inflammatory mediators present in wounds, such as transforming growth factor-beta (TGF- $\beta$ ) $[255,256]$. Importantly, TGF- $\beta$ has been shown to modulate Fn production from airway epithelial cells in vitro $[253,257]$. There are multiple sources of TGF- $\beta$ in the airways, but bronchial epithelial cells themselves produce TGF- $\beta$ which can function in an autocrine/paracrine fashion to influence epithelial cell phenotypes, including Fn production and cell morphology [258]. TGF- $\beta$ is also capable of enhancing the expression of the EIIIA Fn splice variant of cultured airway epithelial cells [253]. Additionally, other mediators present in inflamed airways, such as TNF- $\alpha$ and histamine can modulate bronchial epithelial cell Fn production $[259,260]$. Thus, the matrix production by epithelial cells is probably influenced by mediators released from epithelial cells themselves, as well as the "traditional" inflammatory cells of the airway.

The migration of epithelial cells to cover an airway wound is probably a series of complex interactions of epithelial cells with the matrix. In epithelial cell sheet migration assays using video microscopy, both cell spreading at the edge of the wound and migration of epithelial sheets have been observed as early features of repair [261]. Sheet migration is enhanced by Fn and epidermal growth factor (EGF) [262], and impaired by TGF- $\beta$ [263]. TGF- $\beta$ may slow sheet migration, in part, by increasing adhesion of cells to the matrix [263]. Adhesion of epithelial cells is mediated, in part, by receptor interactions with the matrix. Bronchial epithelial cells are known to express both integrin and nonintegrin receptors, which can influence attachment [264-266]. TGF- $\beta$ enhancement of bronchial epithelial cell attachment is mediated, in part, by integrin receptors for Fn and vitronectin [263]. The relative importance of the many aspects of migration at various stages of repair remains an active area of research.

Proliferation and differentiation of epithelial cells are also necessary in the repair of injured epithelium [267]. Inflammatory mediators released by a variety of cells in the airway, including epithelial cells themselves, are known to influence epithelial cell proliferation and differentiation [268, 269]. TGF- $\beta$ inhibits epithelial cell growth and induces squamous differentiation [270, 271]. TGF- $\beta$ from bronchial epithelial cells has been shown to function in an autocrine/paracrine fashion to alter cell morphology [258], and to exert growth regulation [269]. Airway epithelial cell EGF and TGF- $\beta$ are also thought to regulate growth and differentiation of epithelial cells $[269,272]$.

At the alveolar level, the Type I cell is the most easily injured cell. Type I cells, owing to their morphology, are the most exposed cells in the alveolus, and lack the capacity for cellular repair and mitosis. Type I cells can be injured by a wide variety of insults, including inhaled environmental agents, e.g. ozone [273], $\mathrm{NO}_{2}$ [274], and volcanic ash [275], infectious agents, e.g. Pneumocystis carinii [276], and xenobiotics, e.g. cyclophosphamide [277], bleomycin [278], and butylated hydroxytoluene [279]. Type II cells are much more resistant to injury. The normal response to injury of any source is destruction and exfoliation of Type I cells, followed by proliferation of Type II cells [280], and differentiation into the Type I phenotype [280]. However, under conditions of chronic inflammation, Type II hyperplasia results. Hyperplastic Type II cells form a cuboidal epithelium and are hallmarks of such diverse clinical syndromes as idiopathic pulmonary fibrosis and adult respiratory distress syndrome [281].

The control of the proliferative response of Type II cells presumably requires several factors, including loss of contact inhibition by adjacent Type I cells, stimulation with growth factors, and the presence of the appropriate extracellular matrix [282]. A number of growth factors have been identified for cultured Type II cells. These include growth factors such as EGF and TGF- $\alpha$, which have been identified as airway epithelial cell products, raising the possibility that epithelial cell interactions contribute to repair of alveolar injury.

Migration, proliferation, and differentiation of epithelial cells are integral features of the repair process accompanying airway inflammation. Epithelial cell production of a variety of mediators and matrix constituents contribute to the interaction of epithelial cells with one another and the surrounding matrix to accomplish restoration of the epithelium.

\section{Fibroblasts}

Many components of epithelial cell interactions similarly influence surrounding fibroblasts (fig. 2). These epithelial cell-fibroblast interactions also play a significant role in inflammatory repair mechanisms. In vitro, bronchial epithelial cells release factors which influence fibroblast migration [283], growth [284], matrix production [285], and retraction. Fibroblast chemotaxis is known to be influenced by bronchial epithelial cell Fn [286]. TGF$\beta$ modulates fibroblast chemotaxis [287], and, thus, airway epithelial cell TGF- $\beta$ may also be involved in fibroblast migration. TGF- $\beta$ is one of the epithelial cell 


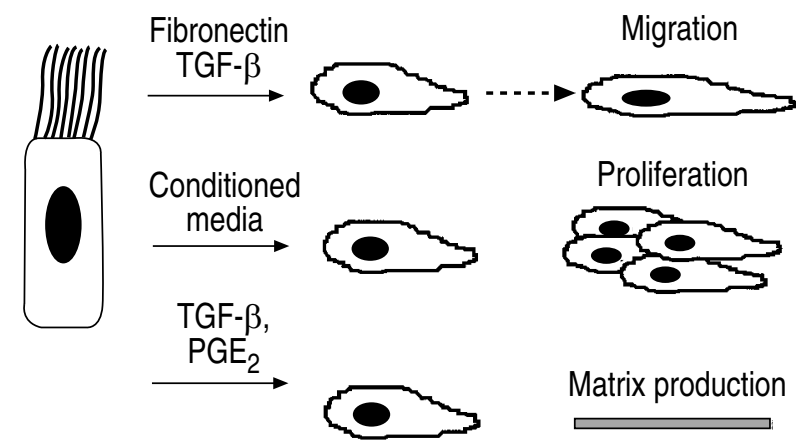

Fig. 2. - Epithelial cells interactions with fibroblasts which may be of import for the repair of injury. Epithelial cells secrete fibronectin and TGF- $\beta$ which may direct fibroblast migration, uncharacterized substances in conditioned media which stimulate fibroblast proliferation, and TGF- $\beta$ and $\mathrm{PGE}_{2}$ which can modulate fibroblast secretion of matrix proteins.

products that appears to increase fibroblast Fn and collagen production [285]. In contrast, $\mathrm{PGE}_{2}$ is released by bronchial epithelial cells [288], and functions to inhibit fibroblast matrix production [285]. A variety of other mediators known to influence matrix production are also expressed by epithelial cells, such as insulin-like growth factor-1 (IGF-1), IL-1, and IL-6, and probably are involved in epithelial cell-fibroblast interactions in airway repair [289].

Supernatants from bronchial epithelial cell cultures have been shown to contain factors which both stimulate and inhibit fibroblast proliferation [290]. The growth stimulatory factor(s) have not been elucidated, and the inhibitory factor(s) are known to include $\mathrm{PGE}_{2}$. In addition, exposure of bronchial epithelial cells in vitro to endotoxin causes an increase in release of $\mathrm{PGE}_{2}$. However, in the presence of indomethacin, endotoxin exposure caused a stimulation of fibroblast proliferation [291]. Thus, epithelial cells may modulate fibroblast growth and mediators of inflammation may influence this epithelialderived growth activity.

Further understanding of repair mechanisms undoubtedly involves better delineation of the interactions of epithelial cell mediators with fibroblasts in vivo. The complexity of these interactions may be increased by the observation that fibroblasts in various locations in the airway may respond differently to inflammatory stimuli [292]. Thus, continued investigations are needed to define epithelial cell-fibroblast interactions in airway injury and repair.

\section{Role in disease}

The pulmonary epithelium is undoubtedly involved in most pulmonary disease processes. Damage can occur to epithelial cells both in the alveoli and in the airways. Damage of Type I alveolar cells is a regular feature of many acute and chronic interstitial lung diseases [293]. Similarly, damage of the airway epithelium is a regular feature in infectious processes, following toxic exposures, and as a result of immune-mediated injury, and is a regular feature of chronic diseases, such as asthma and chronic bronchitis [293].
The precise roles of individual cellular functions in the pathogenesis of specific diseases are incompletely defined. Nevertheless, loss of barrier and transport functions consequent to alveolar epithelial cell damage may contribute significantly to alveolar flooding with protein rich exudates, potentially setting the stage for secondary infections [294]. It is also possible that loss of host defence capabilities may also lead to the increased incidence of infections to which these patients are thought to be susceptible. Similarly, alterations in epithelial cell function could predispose to secondary infection by decreasing clearance, by altering the composition of airway secretions, and by making the airway surface more susceptible to bacterial colonization [1].

Damage of epithelial cells is undoubtedly linked with the initiation of repair processes. Whether started as part of an inflammatory response or as a response to injury, these processes can lead to stimulation of the mesenchymal cells of the lung, and result in permanent alteration of tissue architecture and function. Deposition of increased amounts of collagen, for example, is a regular feature of both acute and chronic interstitial lung diseases, and can result in severe restrictive ventilatory defects [293, 295, 296]. Similarly, accumulation of collagen within the lumen of the airway, for example in bronchiolitis obliterans, or within the airway wall, for example in chronic obstructive pulmonary disease (COPD), can lead to airflow obstruction [293, 297]. Thus, epithelial cells, by virtue of being linked to the responses of other parenchymal cells in the lung, can contribute to the longterm physiological consequences in many conditions. Finally, the stimulation of proliferation of epithelial cells that takes place following many stimuli may play an important role in the development of malignant neoplasms in the lung [298].

\section{Therapeutic perspectives}

There are, at present, no direct therapeutic applications of pulmonary epithelial cell biology which have reached clinical practice. A number of important therapeutic opportunities are, however, on the horizon.

It is likely that current therapies may be targeting the pulmonary epithelium. Cells of the airway epithelium, for example, are importantly involved in the production of mediators in inflammatory diseases, such as asthma and bronchitis. In this regard, airway epithelial cells have receptors for a variety of agents, including betaagonists, acetylcholine, histamine and neuropeptides [1]. It thus seems likely that many well-established therapies may, in part, be due to effects on the airway epithelial surface. The importance of the airway epithelium as a target for widely-used medications is probably only partially explored. Erythromycin, for example, can directly affect epithelial mucin production [299], and such an action may account for the widely-recognized benefits of erythromycin during exacerbations of airways disease.

The ability to deliver therapeutic agents directly to the epithelial surface of the airways offers a number of important opportunities. Gene therapy, for example, can 
be delivered directly to the airway surface using a variety of vectors, including viruses which are "predesigned" to target the airway epithelium [300, 301]. With such approaches, it is possible to introduce novel genetic material into the airway epithelium. Such strategies offer a myriad of therapeutic opportunities. Several protocols for gene therapy for cystic fibrosis are currently in progress. It has proved possible to introduce the CFTR gene into airway epithelial cells. This has been accomplished both in animal models [302, 303], and in human patients [304]. In patients with cystic fibrosis, introduction of the normal gene has been associated with normalization of airway potential differences. It seems likely that with such strategies it will be possible not only to correct underlying genetic defects, but also to modulate epithelial behaviour in acquired diseases.

Airway epithelial cells are also responsible for the production of a number of agents which determine lung function. The use of glucocorticoids to stimulate foetal lung production of surfactant by epithelial cells is a wellestablished therapy aimed indirectly at Type II alveolar epithelial cells [305]. These cells are also importantly involved in other parenchymal lung diseases, including both acute lung injury and chronic interstitial fibrotic disorders [293]. It seems likely that current studies defining the specific mediators released by cells of the alveolar epithelial surface which help to both drive and control these pathophysiological processes will open new therapeutic opportunities.

Finally, cancer frequently originates in the epithelial cells of the airway [298]. How carcinogens, for example from cigarette smoke, interact with cells of the airway and lead to the development of the neoplastic process is an area which has been under investigation for many years. Enzyme systems for xenobiotic metabolism which may activate or inactivate carcinogens have been related to cancer susceptibility. In addition, the genetic basis for the regulatory control of cell proliferation, including both oncogenes and anti-oncogenes, has been intensively studied. Whilst such studies have not yet yielded direct therapeutic information, it seems likely that information gained from such studies will contribute to therapies designed to either limit or treat neoplastic processes.

In conclusion, the pulmonary epithelium is composed of well structured, but heterogenous populations of cells. The cells which reside in the pulmonary epithelium play important roles in the maintenance of normal lung function. The airway epithelium provides a mechanical barrier to the surface of the airway lumen, contributes to host defence through mucociliary clearance and secretion, maintains airway tone by modulating airway smooth muscle and vascular responses, modulates pulmonary inflammatory responses, and directs repair of injury to the airway. The cells which line the alveoli serve predominantly to maintain optimal conditions for gas exchange. However, via the newly recognized immunomodulatory activities of SP-A, lymphocyte inhibitory factor, and expression of ICAM-1, these cells are becoming recognized as participants in local immune responses.

Morphological and functional disordering of the pulmonary epithelium cause hypersecretion, airway obstruction, abnormal fibrotic healing, and, in turn, ventilation/perfusion abnormalities. Hopefully, continuing insight into the cell biology of pulmonary epithelial function will to lead to new, rational therapies directed towards the pathogenesis of lung diseases, thereby preventing the physiological consequences of lung diseases upon their unfortunate victims.

\section{References}

1. Rennard SI, Beckmann JD, Robbins RA. Biology of airway epithelial cells. In: Crystal RG, West JB, eds. The Lung, Scientific Foundations. New York, Raven Press, 1991; pp. 157-167.

2. Breeze RG, Wheeldon EB. The cells of the pulmonary airways. Am Rev Respir Dis 1977; 116: 705-777.

3. Jeffery PK. Morphologic features of airway surface epithelial cells and glands. Am Rev Respir Dis 1983; 128: S14-S20.

4. Jeffery PK. Structure and function of adult tracheobronchial epithelium. In: McDowell EM, ed. Lung Carcinomas. Edinburgh, Churchill-Livingstone, 1987; pp. 42-73.

5. Poitiers WD, Lord PW, Biles B, Whimster WF. Bronchial gland histochemistry in lungs removed for cancer. Thorax 1980; 35: 546-550.

6. Plopper CG, Halesbro JE, Berger WJ, Sonstegard KS, Nettersheim P. Distribution of nonciliated bronchiolar epithelial (Clara) cells in intra- and extrapulmonary airways of the rabbit. Exp Lung Res 1983; 4: 79-98.

7. Plopper CG, Mariassy AT, Wilson DW, Allez JL, Nishio SJ, Nettersheim P. Comparison of nonciliated tracheal epithelial cells in six mammalian species. Exp Lung Res 1983; 5: 281-294.

8. Crapo JD, Barry BE, Gehr P, Bachofen M, Weibel ER. Cell numbers and cell characteristics of the normal human lung. Am Rev Respir Dis 1982; 126: 332-337.

9. Linder J, Rennard SI. In: Bronchoalveolar Lavage. 1st edn. Chicago, ASCP Press, 1988.

10. Jeffrey PK, Reid L. New observations of rat epithelium: a quantitative and electron microscope study. J Anat 1975; 120: 295.

11. Gail DB, Lenfant CJM. State of the art. Cells of the lung: biology and clinical implications. Am Rev Respir Dis 1983; 127: 366-389.

12. Serafini SM, Michaelson ED. Length and distribution of cilia in human and canine airways. Bull Eur Physiopathol Respir 1977; 13: 551-558.

13. Satir P. How cilia move. Sci Am 1974; 231: 45.

14. Gibbons IR. Studies on the protein components from Tetrahymena pyriformis. Proc Natl Acad Sci 1963; 50: 1002.

15. Mariassy AT, Plopper CG. Tracheobronchial epithelium of the sheep. II. Ultrastructural and morphometric analysis of the epithelial secretory cell types. Anat Rec 1984; 209: 523-534.

16. Bucher U, Reid L. Development of the mucus-secreting elements in the human lung. Thorax 1961; 16: 219.

17. McDowell EM, Barrett LA, Glavin F, Harris CC, Trump BF. The respiratory epithelium. I. Human bronchus. J Natl Cancer Inst 1978; 61: 539-549.

18. Rhodin JAG. The ciliated cell: ultrastructure and function of human tracheal mucosa. Am Rev Respir Dis 1966; 93: 1.

19. Ebert RV, Terracio MJ. The bronchiolar epithelium in cigarette smokers: observations with the scanning 
electron microscope. Am Rev Respir Dis 1975; 111: 411.

20. Evans MJ, Cox RJ, Shami SG, Wilson B, Plopper CG. The role of basal cells in attachment of columnar cells to the basal lamina of the trachea. Am J Respir Cell Mol Biol 1989; 1: 463-469.

21. Meyrick B, Reid L. Ultrastructure of cells in the human bronchial submucosal glands. J Anat 1970; 107: 281.

22. Plopper CG, Hill LH, Mariassy AT. Ultrastructure of the nonciliated epithelial (Clara) cell of mammalian lung. III. A study of man with comparison of 15 mammalian species. Exp Lung Res 1980; 1: 171

23. Cutz E, Conen PE. Ultrastructure and cytochemistry of Clara cells. Am J Pathol 1971; 62: 127-141.

24. Broers JLV, Jensen SM, Travis WD, et al. Expression of surfactant-associated protein A and Clara cell 10 kiloDalton mRNA in neoplastic and non-neoplastic human lung tissue as detected by in situ hybridization. Lab Invest 1992; 66: 337-346.

25. Singh G, Singh J, Katyal SL, et al. Identification, cellular localization, isolation and characterization of human Clara cell-specific $10 \mathrm{kD}$ protein. J Histochem Cytochem 1988; 1: 73-80.

26. Gupta RP, Patton SE, Jetten AM, Hook GER. Purification, characterization, and protease inhibitory activity of a Clara cell secretory protein from the pulmonary extracellular lining of rabbits. Biochem J 1987; 248: 337-344.

27. Singh G, Katyal SL, Brown WE, et al. Amino acid and cDNA nucleotide sequences of human Clara cell 10 kDa protein. Biochem Biophys Acta 1988; 950: 329-337.

28. Balis JU, Paterson JF, Paciga JE, Haller EM, Shelley SA. Distribution and subcellular localization of surfactantassociated glycoproteins in human lung. Lab Invest 1985; 52: 657-669.

29. Beckmann JD, Spurzem JR, Rennard SI. Phenol sulfotransferase expression in the airways: enzymological and immunohistochemical demonstration. Cell Tissue Res 1993; 274: 475-485.

30. Terzakis JA, Sommers SC, Anderson B. Neurosecretory appearing cells of human segmental bronchi. Lab Invest 1972; 26: 127-132

31. Sorokin SP, Hoyt RF, Pearsall AD. Comparative biology of small granule cells and neuroepithelial bodies in the respiratory system: a short review. Am Rev Respir Dis 1983; 128: S26-S31.

32. Sorokin SP, Hozt RF Jr. Neuroepithelial bodies and solitary small-granule cells. In: Massaro D, ed. Lung Cell Biology. New York, Marcel Dekker Inc., 1989; pp. 191-344.

33. Tateishi R. Distribution of argyrophil cells in adult human lungs. Arch Pathol 1973; 96: 198-202.

34. Johnson DE. Pulmonary neuroendocrine cells. In: Farmer SG, Hay DWP, eds. The Airway Epithelium: Physiology, Pathology, and Pharmacology. New York, Marcel Dekker Inc., 1991; pp. 335-397.

35. Gould VE, Linnoila RI, Memoli VA, Warren WH. Neuroendocrine components of the bronchopulmonary tract: hyperplasias, dysplasias and neoplasms. Lab Invest 1983; 49: 519-537.

36. Aguayo SM, Miller YE, Waldron JA, et al. Brief report: idiopathic diffuse hyperplasia of pulmonary neuroendocrine cells and airways disease. N Engl J Med 1992; 327: 1285-1288.

37. Pattle RE. Surface lining of lung alveoli. Physiol Rev 1965; 45: 48-79.

38. Weibel ER, Gil J. Electron microscopic demonstration of an extracellular duplex lining layer of alveoli. Respir Physiol 1968; 4: 43-57.

39. Johansson J, Curstedt T, Robertson B. The proteins of the surfactant system. Eur Respir J 1994; 7: 372-391.

40. Hamm H, Fabel H, Bartsch W. The surfactant system of the adult lung: physiology and clinical perspectives. Clin Invest 1992; 70: 637-657.

41. Monkhouse WS, Whimster WF. An account of the longitudinal mucosal corrugations of the human tracheobronchial tree, with observations on those of some animals. $J$ Anat 1976; 122: 681.

42. Weibel ER, Gehr P, Haies D, Gil J, Bachofen M. The cell population of the normal lung. In: Bouhuys A, ed. Lung Cells in Disease. Amsterdam, Elvisier/North Holland, 1976; pp. 3-16.

43. Weibel ER. In: The Pathway for Oxygen. Cambridge, Mass, Harvard University Press, 1984.

44. Adamson IY. Relationship of mesenchymal changes to alveolar epithelial cell differentiation in fetal rat lung. Anat Embryol (Berl) 1992; 185: 275-280.

45. Hislop A, Reid L. Growth and development of the respiratory system. In: Davis JA, Dopping J, eds. Scientific Foundations of Paediatrics. London, Heineman, 1974; pp. 214-254.

46. Bucher U, Reid LM. Development of the intersegmental bronchial tree: the pattern of branching and development of cartilage at various stages of intrauterine life. Thorax 1961; 16: 207-218.

47. Boyden EA, Tompsett DH. The changing patterns in the developing lungs of infants. Acta Anat (Basel) 1965; 61: 164-192.

48. Jeffery PK, Reid LM. Ultrastructure of airway epithelium and submucosal gland during development. In: Hodson WA, ed. Development of the Lung. New York, Marcel Dekker, 1977; pp. 87-134.

49. Adamson IYR. Development of lung structure. In: Crystal RG, West JB, eds. The Lung, Scientific Foundations. New York, Raven Press, 1991; pp. 663-670.

50. Schneeberger EE, Walters DV, Olver RE. Development of intracellular junctions in the pulmonary epithelium of foetal lamb. J Cell Sci 1978; 32: 307-323.

51. Olver RE, Schneeberger EE, Walters DV. Epithelial solute permeability, ion transport and tight junction morphology in the developing lung of the fetal lamb. $J$ Physiol 1981; 315: 395-412.

52. Danto SI, Zabski SM, Crandell ED. Reactivity of alveolar epithelial cells in primary culture with Type I cell monoclonal antibodies. Am J Respir Cell Mol Biol 1992; 6: 296-306.

53. Ten-Have-Opbroek AA, Plopper CG. Morphogenic and functional activity of Type II cells in early fetal Rhesus monkey lungs: a comparison between primates and rodents. Anat Rec 1992; 234: 93-104.

54. Wohlford-Lenane CL, Snyder JM. Localization of surfactant-associated proteins SP-A and SP-B mRNA in rabbit fetal lung tissue by in situ hybridization. Am J Respir Cell Mol Biol 1992; 7: 335-343.

55. Kotas RV, Mims LC, Hart LK. Reversible inhibition of lung cell number after glucocorticoid injection into fetal rabbits to enhance surfactant appearance. Pediatrics 1974; 53: 358-362.

56. Adamson IYR, King GM. Epithelial-interstitial cell interactions in fetal rat lung development accelerated by corticosteroids. Lab Invest 1986; 55: 145-152.

57. Adamson IYR, Bowden DH. Derivation of Type I epithelium from Type II cells in the developing rat lung. Lab Invest 1975; 32: 736-745. 
58. Kauffman SL, Burri PH, Weibel ER. The postnatal growth of the rat lung. II. Autoradiography. Anat Rec 1974; 180: 63-74.

59. Strang LB. Growth and development of the lung: fetal and postnatal. Annu Rev Physiol 1977; 39: 253-276.

60. Dawes GS, Fox HE, Leduc BM, Liggins GC, Richards RT. Respiratory movements and rapid eye movement sleep in the foetal lamb. J Physiol (Lond) 1972; 220: 119-143.

61. McCray PB. Spontaneous contractility of human fetal airway smooth muscle: spontaneous contractility of human fetal airway smooth muscle. Am J Respir Cell Mol Biol 1993; 8: 573-580.

62. Adamson TM, Boyd RDH, Platt HS, Strang LB. Composition of alveolar liquid in the foetal lamb. $J$ Physiol (Lond) 1969; 204: 159-169.

63. McCray PB Jr, Bettencourt JD, Bastacky J. Developing bronchopulmonary epithelium of the human fetus secretes fluid. Am J Physiol 1992; 262: L270-L279.

64. McCray PB Jr, Reenstra WW, Louie E, Johnson J, Bettencourt JD, Bastacky J. Expression of CFTR and presence of cAMP-mediated fluid secretion in human fetal lung. Am J Physiol 1992; 262: L472-L481.

65. McCray PB Jr, Bettencourt JD, Bastacky J. Secretion of lung fluid by the developing fetal rat alveolar epithelium in organ culture. Am J Respir Cell Mol Biol 1992; 6: 609-616.

66. McCray PB Jr, Wohlford-Lenane CL, Snyder JM. Localization of cystic fibrosis transmembrane conductance regulator mRNA in human fetal lung tissue by in situ hybridization. J Clin Inv 1992; 90: 619-625.

67. McCray PB, Bettencourt JD, Bastacky J, Denning GM, Welsh MJ. Expresion of CFTR and a cAMP-stimulated chloride secretory current in cultured human fetal alveolar epithelial cells. Am J Respir Cell Mol Biol 1993; 9: $578-585$.

68. Froh D, Gonzales LW, Ballard PL. Secretion of surfactant protein A and phosphatidylcholine from Type II cells of human fetal lung. Am J Respir Cell Mol Biol 1993; 8: $556-561$.

69. Wang J, Souza P, Kuliszewski M, Tanswell AK, Post M. Expression of surfactant proteins in embryonic rat lung. Am J Respir Cell Mol Biol 1994; 10: 222-229.

70. Schneeberger EE, Walters DV, Olver RE. Development of intercellular junctions in the pulmonary epithelium of the foetal lamb. J Cell Sci 1978; 32: 307-324.

71. Gumbiner B. Structure, biochemistry and assembly of epithelial tight junctions. Am J Physiol 1987; 253: C749-C758.

72. Widdicombe JH. Electrical methods for studying ion and fluid transport across airway epithelia. In: Braga PC, Allergra L, eds. Methods in Mucology. New York, Raven Press, 1988; pp. 335-345.

73. Barnes PJ. State of art: neural control of human airways in health and disease. Am Rev Respir Dis 1986; 134: 1289-1314.

74. Schwarz LB, Huff TF. Mast cells. In: Crystal RB, West JB, Barnes PJ, Cherniack NS, Weibel ER, eds. The Lung: Scientific Foundations. New York, Raven Press, 1991; pp. 601-616.

75. Rickard KA, Taylor J, Rennard SI. Observations of development of resistance to detachment of cultured bovine bronchial epithelial cells in response to protease treatment. Am J Respir Cell Mol Biol 1992; 6: 414-420.

76. Plotkowski MC, Bajolet-Laudinet O, Puchelle E. Cellular and molecular mechanisms of bacterial adhesion to respiratory mucosa. Eur Respir J 1993; 6: 903-916.
77. Tuomanen E, Hendley JO. Adherence of Bordetella pertussis to human respiratory epithelial cells. J Infect Dis 1983; 148: 125-130.

78. Collier AM, Clyde WA Jr, Denny FW. Mycoplasma pneumoniae in hamster tracheal organ culture: immunofluorescent and electron microscope studies. Proc Soc Exp Biol Med 1971; 136: 569-573.

79. Plotkowski MC, Puchelle E, Beck G, Jacquot J, Hannoun C. Adherence of Type I Streptococcus pneumoniae to tracheal epithelium of mice infected with influenza A/PR8 virus. Am Rev Respir Dis 1986; 134: 1040-1044.

80. Schwarzmann SW, Adler JL, Sullivan RJ Jr, Marine WM. Bacterial pneumonia during the Hong Kong influenza epidemic of 1968-1969: experience in a city-county hospital. Arch Intern Med 1971; 127: 1037-1041.

81. Chodosh S. Acute bacterial exacerbations in bronchitis and asthma. Am J Med 1987; 82 (Suppl. 4a): 154163.

82. Thompson AB, Schultz HD, Sisson JH, Rennard SI. Airway mucociliary clearance. In: Bone RC, Dantzker DR, George RB, Matthay RA, Reynolds HY, eds. Pulmonary and Critical Care Medicine. St. Louis, Mosby Year Book, 1992; pp. E3: 1-12.

83. Silverberg A. Biorheological matching: mucociliary interaction and epithelial clearance. Biorheology 1983; 20: $215-222$.

84. Iravani J, Van As A. Mucus transport in the tracheobronchial tree of normal and bronchitic rats. J Pathol 1972; 106: 81-93.

85. Hunninghake G, Crystal R. Cigarette smoking and lung destruction: accumulation of neutrophils in the lungs of cigarette smokers. Am Rev Respir Dis 1983; 128: 833838.

86. Burman WJ, Martin WJ. Oxidant-mediated ciliary dysfunction: possible role in airway disease. Chest 1986; 89: 410-413.

87. Dorinsky PM, Davis WB. Chronic bronchitis: oxidant damage by leukocytes. Chest 1986; 89: 321-322.

88. Tegner H, Ohlsson K, Toremalm NG, von Mecklenburg C. Effect of human leukocyte enzymes on tracheal mucosa and its mucociliary activity. Rhinology 1979; 17: 199-206.

89. Sisson J, Prescott S, McIntyre T, Zimmerman G. Production of platelet-activating factor by stimulated human polymorphonuclear leukocytes: correlation of synthesis with release, functional events, and leukotriene $\mathrm{B}_{4}$ metabolism. J Immunol 1987; 138: 3918-3926.

90. Seybold Z, Mariassy A, Stroh D, Kim C, Gazeroglu H, Wanner A. Mucociliary interaction in vitro: effects of physiological and inflammatory stimuli. J Appl Physiol 1990; 68: 1421-1426.

91. Jain B, Robbins R, Rubinstein I, Sisson J. TNF- $\alpha$ and IL-1 $\beta$ modulate airway epithelial ciliary activity by a nitric oxide-dependent mechanism. Clin Res 1994; 42: 115A.

92. Jain B, Rubinstein I, Robbins RA, Leise KL, Sisson JH. Modulation of airway epithelial cell ciliary beat frequency by nitric oxide. Biochem Biophys Res Commun 1993; 191: 83-88

93. Sanderson M, Dirksen E. Mechanosensitive and betaadrenergic control of the ciliary beat frequency of mammalian respiratory tract cells in culture. Am Rev Respir Dis 1989; 139: 432-440.

94. Yeates D, Spektor D, Pitt B. Effect of orally administered orciprenaline on tracheobronchial mucociliary clearance. Eur J Respir Dis 1986; 69: 100-108.

95. Foster W, Langenback E, Bohning D, Bergofsky E. 
Quantitation of mucus clearance in peripheral lung and comparison with tracheal and bronchial mucus transport velocities in man: adrenergics return depressed clearance and transport velocities in asthmatics to normal. Am Rev Respir Dis 1978; 117: 337.

96. Tamaoki J, Kobayaski K, Sakai N, Chiyotani A, Kanemura T, Takizawa T. Effect of bradykinin on airway ciliary motility and its modulation by neutral endopeptidase. Am Rev Respir Dis 1989; 140: 430-435.

97. Lindberg S, Mercke U. Bradykinin accelerates mucociliary activity in rabbit maxillary sinus. Acta Otolaryngol (Stock) 1988; 101: 114-121.

98. Yeates D, Wong L, Miller I. Stimulation of ciliary beat frequency by bradykinin. Eur Respir J 1988; 1: 114s.

99. Khan A, Bengtsson B, Lindberg S. Influence of substance $\mathrm{P}$ on ciliary beat frequency in airway isolated preparations. Eur J Pharmacol 1986; 130: 91-96.

100. Lindberg S, Mercke U, Uddman R. The morphological basis for the effect of substance $P$ on mucociliary activity in rabbit maxilliary sinus. Acta Otolaryngol (Stockh) 1986; 101: 314-319.

101. Hastie AT, Loegering DA, Gleich GJ, Kueppers F. The effect of purified human eosinophil major basic protein on mammalian ciliary activity. Am Rev Respir Dis 1987; 135: 848-853.

102. Devalia JL, Saosford RJ, Rusznak C, Davies R. The effect of human eosinophils on cultured human nasal epithelial cell activity and the influence of nedocromil sodium in vitro. Am J Respir Cell Mol Biol 1992; 7: 270-277.

103. Wanner A, Maurer D, Abraham W, Szepfalusi Z, Sielczak M. Effects of chemical mediators of anaphylaxis on ciliary function. J Allergy Clin Immunol 1983; 72: 663-667.

104. Mussatto D, Lourenco R. The effect of inhaled histamine on human tracheal mucus velocity and bronchial mucociliary clearance. Am Rev Respir Dis 1988; 138: 775-779.

105. Bisgaard H, Pedersen M. SRS-A leukotrienes decreases the activity of human respiratory cilia. Clin Allergy 1987; 17: 95-103.

106. Robbins RA, Springall DR, Warren JB, et al. Inducible nitric oxide synthase is increased in murine lung epithelial cells by cytokine stimulation. Biochem Biophys Res Commun 1994; 198: 835-843.

107. Coonrod JD. The role of extracellular bactericidal factors in pulmonary host defense. Semin Respir Infect 1986; 1: 118-129.

108. Ellison RT, Giehl TJ. Killing of Gram-negative bacteria by lactoferrin and lysozyme. J Clin Invest 1991; 88: 1080-1091.

109. Arnold RR, Cole MF, McGhee JR. A bactericidal effect for human lactoferrin. Science 1977; 197: 263-265.

110. Bullen JJ, Armstrong JA. The role of lactoferrin in the bactericidal function of polymorphonuclear leucocytes. Immunol 1979; 36: 781-791.

111. Arnold RR, Russell JE, Champion WJ, Brewer M, Gauthier JJ. Bactericidal activity of human lactoferrin: differentiation from the stasis of iron deprivation. Infect Immun 1982; 35: 792-799.

112. Rothman BL, Merrow M, Bamba M, Kennedy T, Kreutzer DL. Biosynthesis of the third and fifth complement components by isolated human lung cells. Am Rev Respir Dis 1989; 139: 212-220.

113. Voss T, Eistetter KP, Schäfer KP, Engel J. Macromolecular organization of natural and recombinant lung surfactant protein SP 28-36. J Mol Biol 1988; 201: 219-227.
114. Tenner AJ, Robinson SL, Borchelt J, Wright JR. Human pulmonary surfactant protein (SP-A), a protein structurally homologous to C1q, can enhance FcR- and CR1mediated phagocytosis. J Biol Chem 1989; 264: 13923-13928.

115. Bjorkander J, Bake B, Oxelius V-A, Hanson LA. Impaired lung function in patients with IgA deficiency and low levels of $\mathrm{IgG}_{2}$ or $\mathrm{IgG}_{3}$. N Engl J Med 1985; 313: 720-724.

116. Mostov KE, Simister NE. Transcytosis. Cell 1985; 43: 389-390.

117. Waldman RH, Ganguly R. Immunity to infections on secretory surfaces. J Infect Dis 1974; 130: 419-420.

118. Bullen JJ, Rogers HJ, Griffiths E. Role of iron in bacterial infection. Curr Top Microbiol Immunol 1978; 80: $1-35$.

119. Church DF, Pryor WA. Free-radical chemistry of cigarette smoke and its toxicological implications. Environ Health Perspect 1985; 64: 111-126.

120. Halliwell B, Gutteridge JMC. In: Free Radicals in Biology and Medicine. 2nd edn. Oxford, Claredon Press, 1989.

121. Hoidal JR, Fox RB, Lemarbe PA, Perri R, Repine JE. Altered oxidative metabolic responses in vitro of alveolar macrophages from asymptomatic cigarette smokers. Am Rev Respir Dis 1981; 123: 85-89.

122. Ludwig PW, Hoidal JR. Alterations in leukocyte oxidative metabolism in cigarette smokers. Am Rev Respir Dis 1982; 126: 977-980.

123. Richter AM, Abboud RT, Johal SS, Ferra TA. Acute effect of smoking on superoxide by pulmonary alveolar macrophages. Lung 1986; 164: 233-242.

124. Heffner JE, Repine JE. Pulmonary strategies of antioxidant defense. Am Rev Respir Dis 1989; 140: 531-554.

125. Winterbourn CC, Molloy AL. Susceptibilities of lactoferrin and transferrin to myeloperoxidase-dependent loss of ironbinding capacity. Biochem J 1988; 250: 613-616.

126. Halliwell B, Aruoma OI, Wasil M, Gutteridge JMC. The resistance of transferrin, lactoferrin, and caeruloplasmin to oxidative damage (Letter). Biochem J 1988; 256: 311.

127. Mazurier J, Metz-Boutique M-H, Jolles J, Spik G, Montreuil J, Jolles P. Human lactoferrin: molecular, functional and evolutionary comparisons with human serum transferrin and hen ovotransferrin. Experientia 1983; 39: 135141.

128. Katsura H, Kawada H, Konno K. Rat surfactant apoprotein A (SP-A) exhibits antioxidant effects on alveolar macrophages. Am J Respir Cell Mol Biol 1993; 9: 520-525.

129. Cantin AM, Hubbard RC, Crystal RG. Glutathione deficiency in the epithelial lining fluid of the lower respiratory tract of patients with idiopathic pulmonary fibrosis. Am Rev Respir Dis 1989; 139: 370-372.

130. Cantin AM, North SL, Hubbard RC, Crystal RC. Normal alveolar epithelial lining fluid contains high levels of glutathione. J Appl Physiol 1987; 63: 152-157.

131. Pacht ER, Davis WB. Role of transferrin and ceruloplasmin in antioxidant activity of lung epithelial lining fluid. J Appl Physiol 1988; 64: 2092-2099.

132. Thompson AB, Heires A, Bohling T, Von Essen S, Rennard SI. The antioxidant activity of bronchoalveolar lavage fluid is diminished in association with chronic bronchitis. Am Rev Respir Dis 1991; 143: A742.

133. Maier K, Leuschel L, Costabel U. Increased levels of oxidized methionine residues in bronchoalveolar lavage fluid proteins from patients with idiopathic pulmonary fibrosis. Am Rev Respir Dis 1991; 143: 271-274.

134. Malech HL, Gallin JI. Neutrophils in human diseases. N Engl J Med 1987; 317: 687-694. 
135. Sallenave J-M, Silva A, Marsden ME, Ryle AP. Secretion of mucus proteinase inhibitor and elafin by Clara cell and Type II pneumocyte cell lines. Am J Respir Cell Mol Biol 1993; 8: 126-133.

136. Abe T, Kobayashi N, Yoshimura K, et al. Expression of the secretory leukoprotease inhibitor gene in epithelial cells. J Clin Invest 1991; 87: 2207-2215.

137. Mooren HWD, Kramps JA, Franken C, Meijer CJLM, Dijkman JA. Localisation of a low-molecular-weight bronchial protease inhibitor in the peripheral human lung. Thorax 1983; 38: 180-183.

138. Franken C, Meijer CJLM, Dijkman JH. Tissue distribution of antileukoprotease and lysozyme in humans. J Histochem Cytochem 1989; 37: 493-498.

139. Stockley RA, Morrison HM, Smith S, Tetley T. Low molecular mass bronchial proteinase inhibitor and alpha ${ }_{1}^{-}$ proteinase inhibitor in sputum and bronchoalveolar lavage. Hoppe-Seylers Z Physiol Chem 1984; 365: 587-595.

140. Vogelmeier C, Hubbard RC, Fells GA, et al. Antineutrophil elastase defense of the normal human respiratory epithelial surface provided by the secretory leukoprotease inhibitor. J Clin Invest 1991; 87: 482-488.

141. Janoff A, Raju L, Dearing R. Levels of elastase activity in bronchoalveolar lavage fluids of healthy smokers and nonsmokers. Am Rev Respir Dis 1983; 127: 540-544.

142. Snider GL. Pathogenesis of emphysema and chronic bronchitis. Med Clin North Am 1981; 65: 647-665.

143. Sommerhoff CP, Nadel JA, Basbaum CB, Caughey GH. Neutrophil elastase and cathepsin G stimulate secretion from cultured bovine airway gland serous cells. J Clin Invest 1990; 85: 682-689.

144. Rennard SI, Beckman J, Daughton D, et al. The role of airway epithelium in cellular migration. In: Farmer SG, Hay DWP, eds. The Airway Epithelium: Physiology, Pathophysiology and Pharmacology. 1st edn. New York, Marcel Dekker Inc., 1991; pp. 117-134.

145. Shoji S, Ertl R, Rennard SI. Cigarette smoke stimulates release of neutrophil chemotactic activity from cultured bronchial epithelial cells. Clin Res 1987; 35: 539A.

146. Koyama S, Rennard SI, Leikauf GD, et al. Endotoxin stimulates bronchial epithelial cells to release chemotactic factors for neutrophils. J Immunol 1991; 147: 42934301.

147. Von Essen SG, Robbins RA, Thompson AB, Entl RF, Rennard SI. Mechanisms of neutrophil recruitment to the lung by grain dust exposure. Am Rev Respir Dis 1988; 138: 921-927.

148. Raz M, Robbins RA, Kelling CL, et al. Viral infection of bovine bronchial epithelial cells induces increased neutrophil chemotactic activity and neutrophil adhesion. Clin Sci 1993; 85: 753-760.

149. Shoji S, Ertl R, Rennard SI. Cigarette smoke stimulates release of neutrophil chemotactic activity from cultured bronchial epithelial cells. Clin Res 1987; 35: 539a.

150. McElvaney NG, Nakamura H, Birrer P, et al. Modulation of airway inflammation in cystic fibrosis: in vivo suppression of interleukin-8 levels on the respiratory epithelial surface by aerosolization of recombinant secretory leukoprotease inhibitor. J Clin Invest 1992; 90: 1296-1301.

151. Davis PB, Silski C, Kersmar C. Beta-adrenergic receptors in human tracheal epithelial cells in primary culture. Am J Physiol 1990; 258: C71-C76.

152. Beckmann JD, Romberger D, Taylor J, Rennard SI, Spurzem JR. Stimulation of bovine bronchial epithelial cell migration and chemotaxis by tetradecanoyl phorbal acetate (TPA). Am J Respir Crit Care Med 1994; 149: A999.
153. Eling TE, Danilowicz RM, Henke DC, Sivarajah K, Yankaskas JR, Boucher RC. Arachidonic acid metabolism by canine tracheal epithelial cells. J Biol Chem 1986; 261: 12841-12849.

154. Holtzman MJ, Aizawa H, Nadel JA, Goetzl EJ. Selective generation of leukotriene $\mathrm{B}_{4}$ by tracheal epithelial cells from dogs. Biochem Biophys Res Commun 1983; 114: 1071-1076.

155. Koyama S, Rennard SI, Leikauf GD, Robbins RA. Bronchial epithelial cells release monocyte chemotactic activity in response to smoke and endotoxin. J Immunol 1991; 147: 972-979.

156. Schall TJ. Biology of the RANTES/sis cytokine family. Cytokine 1991; 3: 165-183.

157. Standiford TJ, Kunkel SL, Basha MA, et al. Interleukin8 gene expression by a pulmonary epithelial cell line: a model for cytokine networks in the lung. J Clin Invest 1990; 86: 1945-1953.

158. Levine SJ, Larivee P, Logun C, Angus CW, Shelhamer $\mathrm{JH}$. Corticosteroids differentially regulate secretion of IL-6, IL-8, and G-CSF by a human bronchial epithelial cell line. Am J Physiol 1993; 265: L360-L368.

159. Nakamura H, Yoshimura K, McElvaney NG, Crystal RG. Neutrophil elastase in respiratory epithelial lining fluid of individuals with cystic fibrosis induces interleukin-8 gene expression in a human bronchial epithelial cell line. J Clin Invest 1992; 89: 1478-1484.

160. Mio T, Adachi Y, Romberger DJ, Illig MG, Robbins RA, Rennard SI. Modulation of IL-8 release from human bronchial epithelial cells by tumor necrosis factor- $\alpha$ enodtoxin and cigarette smoke. Am J Respir Crit Care Med 1994; 149: A1070.

161. Blusse Van Oud Alblas A, Van Furth R. Origin, kinetics, and characteristics of pulmonary macrophages in the steady-state. J Exp Med 1979; 149: 1504-1518.

162. Kwon OJ, Jose PJ, Robbins RA, Schall TJ, Williams TJ, Barnes PJ. Dexamethasone inhibition RANTES expression in cultured human lung epithelial cells. Am J Respir Crit Care Med 1994; 149: A944.

163. Rot A, Kreiger M, Brunner T, Bischoff SC, Schall TJ, Dahinden CA. RANTES and macrophage inflammatory protein-1a induce the migration and activation of normal human eosinophil granulocytes. J Exp Med 1992; 176: $1489-1495$.

164. Ford-Hutchinson AW, Bray MA, Doig MV, Shipley ME, Smith MJH. Leukotriene $\mathrm{B}_{4}$, a potent chemokinetic and aggregating substance released from polymorphonuclear leukocytes. Nature 1980; 286: 264-265.

165. Holtzman MJ, Ferdman B, Bohrer A, Turk J. Synthesis of the 1-0-hexadecyl species of platelet-activating factor by airway epithelial and vascular endothelial cells. Biochem Biophys Res Commun 1991; 177: 357-364.

166. Tamura N, Agrawal DK, Suliaman FA, Townley RG. Effects of platelet-activating factor on the chemotaxis of normodense eosinophils from normal subjects. Biochem Biophys Res Commun 1987; 142: 638-644.

167. Robbins RA, Shoji S, Gossman GL, Klassen LW, Linder J, Rennard SI. Bronchial epithelial cells release chemotactic activity for lymphocytes. Am J Physiol 1989; 257: L109-L115.

168. Mibu Y, Shimokaway S, Hayashi H. Lymphocyte chemotaxis in inflammation. X. Heterogeneity of chemotactic responsiveness in human T-subsets towards lymphocyte chemotactic factors from delayed hypersensitivity reaction site. Immunology 1985; 55: 473479.

169. Dustin ML, Rothlein R, Bhan AK, Dinarello CA, Springer 
TA. Induction of IL-1 and interferon-gamma: tissue distribution, biochemistry, and function of a natural adherence molecule (ICAM-1). J Immunol 1986; 137: 245-254.

170. Kishimoto TK, Larson RS, Corbi AL, Dustin ML, Staunton $\mathrm{DE}$, Springer TA. The leukocyte integrins. Adv Immunol 1989; 46: 149-182.

171. Simon RH, DeHurt PD, Todd RF. Neutrophil-induced injury of rat pulmonary alveolar epithelial cells. J Clin Invest 1986; 78: 1375-1386.

172. Rothlein R, Czajkowski M, O'Neill MM, Marlin SD, Mainolfi E, Merluzzi VJ. Induction of intercellular adhesion molecule- 1 on primary and continuous cell lines by proinflammatory cytokines. J Immunol 1988; 141: 1665-1669.

173. Wegner CD, Gundel RH, Reilly P, Haynes N, Letts LG, Rothlein R. Intercellular adhesion molecule-1 (ICAM1) in the pathogenesis of asthma. Science 1990; 2: 456-459.

174. Manolitsas ND, Trigg CJ, McAuley AE, et al. The expression of the $\beta_{1}$-integrins in asthma. Eur Respir $J$ 1994; 7: 1439-1444.

175. Christensen PJ, Kim S, Simon RH, Toews GB, Paine R III. Differentiation-related expression of ICAM-1 by rat alveolar epithelial cells. Am J Respir Cell Mol Biol 1993; 8: 1994.

176. Kang B-H, Crapo JD, Wegner CD, Letts G, Chang LY. Intercellular adhesion molecule-1 on the alveolar epithelium and its modification by hyperoxia. Am J Respir Cell Mol Biol 1993; 9: 350-355.

177. Guzman J, Izumi T, Nagai S, Costabel U. ICAM-1 and integrin expression on isolated human alveolar Type II pneumocytes. Eur Respir J 1994; 7: 736-739.

178. Taylor PM, Rose ML, Yacoub MH. Expression of MHC antigens in normal human lungs and transplanted lungs with obliterative bronchiolitis. Transplantation 1989; 48 : 506-510.

179. Rossi GA, Sacco O, Balbi B, et al. Human ciliated bronchial epithelial cells: expression of the HLA-DR antigens and of the HLA-DR alpha gene, modulation of the HLA-DR antigens by gamma-interferon, and antigenpresenting function in the mixed leukocyte reaction. $A m$ J Respir Cell Mol Biol 1990; 3: 431-439.

180. Spurzem JR, Sacco O, Rossi GA, Beckmann JD, Rennard SI. Regulation of major histocompatibility complex class II gene expression on bovine bronchial epithelial cells. J Lab Clin Med 1992; 120: 94-102.

181. Guzman J, Izumi T, Nagai S, Costabel U. Immunocytochemical characterization of isolated Type II cells. Acta Cytol 1994; 38: 539-542.

182. Yousem SA, Curley JM, Dauber J, et al. HLA-class II antigen expression in human heart-lung allografts. Transplantation 1990; 49: 991-995.

183. Burke CM, Glanville AR, Theodore J, Robin Ed. Lung immunogenicity, rejection, and obliterative bronchiolitis. Chest 1987; 92: 547-549.

184. Sviland L, Pearson ADJ, Green MA, et al. Expression of MHC class I and II antigens by keratinocytes and enterocytes in acute graft-versus-host disease. Bone Marrow Trans 1989; 4: 233-238.

185. Rossi GA, Sacco O, Balbi B, et al. Human ciliated bronchial epithelial cells: expression of the HLA-DR antigens and of the HLA-DR alpha gene, modulation of the HLA-DR antigens by gamma-interferon and antigenpresenting function in the mixed leukocyte reaction. Am J Respir Cell Mol Biol 1990; 3: 431-439.

186. Spurzem JR, Sacco O, Rossi GA, Beckman JD, Rennard
SI. Regulation of major histocompatibility complex, class II gene expression on bovine bronchial epithelial cells. J Lab Clin Med 1992; 120: 94-102.

187. Nickoloff BJ, Mitra RS, Green J, Shimizu Y, Thompson $\mathrm{C}$, Turka LA. Accessory cell function of keratinocytes for superantigen: dependence on LFA-1/ICAM-1 interaction. J Immunol 1993; 150: 2148-2159.

188. Udey MC, Peck RD, Pentland AP, Schreiner GF, Lefkowith JB. Antigen-presenting cells in essential fatty aciddeficient murine epidermis: keratinocytes bearing class II (Ia) antigens may potentiate the accessory cell function of Langerhans' cells. J Invest Dermatol 1991; 96: 950958.

189. Bland PW, Warren LG. Antigen presentation by epithelial cells of the rat small intestine. I. Kinetics, antigen specificity and blocking by anti-Ia antisera. Immunol 1990; 171: 327-332.

190. Mayer L, Shlien R. Evidence for function of Ia molecules on gut epithelial cells in man. J Exp Med 1987; 166: 1471-1483.

191. Denburg JA, Dolovich J, Ohtoshi T, Cox G, Gauldie J, Jordana M. The microenvironmental differentiation hypothesis of airway inflammation. Am J Rhinol 1990; 4: 29-34.

192. Martin TR, Pistorese BP, Chi EY, Matthay MA. The effects of leukotriene $\mathrm{B}_{4}$ in the human lung: recruitment of active neutrophils into the alveolar spaces without a change in protein permeability. J Clin Invest 1989; 84: $1609-1619$.

193. Samuelsson B. Leukotrienes: mediators of immediate hypersensitivity reactions and inflammation. Science 1983; 220: 568-575.

194. Jordana M, Clancy R, Dolovich J, Denburg J. Effector role of the epithelial compartment in inflammation. Ann New York Acad Sci 1992; 664: 180-189.

195. Cox G, Gauldie J, Jordana M. Bronchial epithelial cellderived cytokines (G-CSF and GM-CSF) promote the survival of peripheral blood neutrophils in vitro. Am J Respir Cell Mol Biol 1992; 7: 507-513.

196. Xhou X, Ohtoshi T, Ralph P, Gauldie J, Jordana M. Human upper airway structural cell-derived cytokines support human peripheral blood monocyte survival: a potential mechanism for monocyte/macrophage accumulation in the tissue. Am J Respir Cell Mol Biol 1992; 6: 212-218.

197. Cox G, Ohtoshi T, Vancheri C, et al. Promotion of eosinophil survival by human bronchial epithelial cells and its modulation by steroids. Am J Respir Cell Mol Biol 1991; 4: 525-531.

198. Ohtoshi T, Vancheri C, Cox G, et al. Monocyte-macrophage differentiation induced by human upper airway epithelial cells. Am J Respir Cell Mol Biol 1991; 4: 255-263.

199. Ohtoshi T, Tsuda T, Vancheri C, et al. Human upper airway epithelial cell-derived granulocyte-macrophage colony-stimulating factor induces histamine-containing cell differentiation of human progenitor cells. Int Arch Allergy Appl Immunol 1991; 95: 376-384.

200. Marini M, Soloperto M, Mezzetti M, Fasoli A, Mattoli S. Interleukin-1 binds to specific receptors on human bronchial epithelial cells and upregulates granulocyte/ macrophage colony-stimulating factor synthesis and release. Am J Respir Cell Mol Biol 1991; 4: 519-524.

201. Palmer RMJ, Ashon DS, Moncada S. Vascular endothelial cells synthesize nitric oxide from L-arginine. Nature (Lond) 1988; 333: 664-666.

202. Moncada S, Higgs A. The L-arginine-nitric oxide pathway. $N$ Engl J Med 1993; 329: 2002-2010. 
203. Yamauchi K, Martinet Y, Basset P, Fells GA, Crystal RG. High levels of transforming growth factor- $\beta$ are present in the epithelial lining fluid of the normal human lower respiratory tract. Am Rev Respir Dis 1988; 137: 1360-1363.

204. Khalil N, O'Connor RN, Unruh HW, et al. Increased production and immunohistochemical localization of transforming growth factor- $\beta$ in idiopathic pulmonary fibrosis. Am J Respir Cell Mol Biol 1991; 5: 155-162.

205. Kehrl JH, Wakefield LM, Roberts AB, et al. Production of transforming growth factor- $\beta$ by human T-lymphocytes and its potential role in the regulation of $\mathrm{T}$ cell growth. J Exp Med 1986; 163: 1037-1050.

206. Espevik T, Figari IS, Shalaby MR, et al. Inhibition of cytokine production by cyclosporin A and transforming growth factor- $\beta$. J Exp Med 1987; 166: 571-576.

207. Sacco O, Romberger D, Rizzino A, Beckmann JD, Rennard SI, Spurzem JR. Spontaneous production of transforming growth factor- $\beta_{2}$ by primary cultures of bronchial epithelial cells: effects on cell behavior in vitro. J Clin Invest 1992; 90: 1379-1385.

208. Steigerwalt RW, Rundhaug JE, Nettesheim P. Transformed rat tracheal epithelial cells exhibit alterations in transforming growth factor- $\beta$ secretion and responsiveness. Mol Carcinog 1992; 5: 32-40.

209. Pelton RW, Johnson MD, Perkett EA, Gold LI, Moses HL. Expression of transforming growth factor $-\beta_{1},-\beta_{2}$, and $-\beta_{3}$ mRNA and protein in the murine lung. $A m J$ Respir Cell Mol Biol 1991; 5: 522-530.

210. Assoian RK, Fleurdelys BE, Stevenson HC, et al. Expression and secretion of type- $\beta$ transforming growth factor by activated human macrophages. Proc Natl Acad Sci USA 1987; 84: 6020-6024.

211. Christman JW, Christman BW, Shepherd VL, Rinaldo JE. Regulation of alveolar macrophage production of chemoattractants by leukotrine $\mathrm{B}_{4}$ and prostaglandin $\mathrm{E}_{2}$. Am J Respir Cell Mol Biol 1991; 5: 297-304.

212. Ulich TR, Yin S, Guo K, Yi ES, Remick D, del Castillo $\mathrm{J}$. Intratracheal injection of endotoxin and cytokines. II. Interleukin- 6 and transforming growth factor- $\beta$ inhibit acute inflammation. Am J Pathol 1991; 138: 1097- 1101.

213. Paine R, II, Chavis A, Gaposchkin D, et al. A factor secreted by human pulmonary alveolar epithelial-like cell line blocks T-cell proliferation between $\mathrm{G}_{1}$ and $\mathrm{S}$ phase. Am J Respir Cell Mol Biol 1992; 6: 658-666.

214. Baughman RP, Strohofer S. Lung-derived surface active material (SAM) inhibits natural killer cell tumor cytotoxity. J Clin Lab Immunol 1989; 28: 51-54.

215. Catanzaro A, Richman P, Batcher S, Hallman M. Immunomodulation by pulmonary surfactant. J Lab Clin Med 1988; 112: 727-734.

216. Sitrin RG, Ansfield MJ, Kaltreider HB. The effect of pulmonary surface-active material on the generation and expression of murine B- and T-lymphocyte effector functions in vitro. Exp Lun Res 1985; 9: 85-97.

217. Wilsher ML, Hughes DA, Haslam PI. Immunoregulatory properties of pulmonary surfactant: effect of lung lining fluid on proliferation of human blood lymphocytes. Thorax 1988; 43: 354-359.

218. Wilsher ML, Parker DJ, Haslam PI. Immunosuppression by pulmonary surfactant: mechanisms of action. Thorax 1990; 45: 3-8.

219. Van Iwaarden F, Welmers B, Verhoef J, Haagsman HP, van Golde LMG. Pulmonary surfactant protein A enhances the host-defence mechanism of rat alveolar macrophages. Am J Respir Cell Mol Biol 1990; 2: 91-98.

220. Schwartz LW, Christman CA. Alveolar macrophage migration: influence of lung lining material. Am Rev Respir Dis 1979; 120: 429-439.

221. O'Neill S, Lesperance E, Klass DJ. Rat lung lavage surfactant enhances bacterial phagocytosis and intracellular killing by alveolar macrophages. Am Rev Respir Dis 1984; 130: 225-230.

222. Van Iwaarden F, van Strijp JA, Ebskamp MJ, Welmers AC, Verhoef J, van Golde LM. Surfactant protein A is opsonin in phagocysosis of Herpes simplex virus type I by rat alveolar macrophages. Am J Physiol 1991; 261: L204-L209.

223. Juers JA, Rogers RM, McCurdy JB, Cook WW. Enhancement of bactericidal capacity of alveolar macrophages by human alveolar lining material. J Clin Invest 1976; 58: 271-275.

224. Baughman RP, Mangels DJ, Strohofer S, Corser BC. Enhancement of macrophage and monocyte cytotoxicity by the surface active material of lung lining fluid. $J \mathrm{Lab}$ Clin Med 1987; 109: 692-697.

225. Manz-Keinke H, Egenhofer C, Plattner H, SchlepperSchaefer J. Specific interaction of lung surfactant protein A (SP-A) with rat alveolar macrophages. Exp Cell Res 1991; 192: 597-603.

226. Black PN, Ghatei MA, Takahashi K, et al. Formation of endothelin by cultured airway epithelial cells. FEBS Lett 1989; 255: 129-132.

227. Holtzman MJ. Arachidonic acid metabolism in airway epithelial cells. Annu Rev Physiol 1992; 54: 303-329.

228. Barnett K, Jacoby DB, Nadel JA, Lazarus SC. The effects of epithelial cell supernatant on contractions of isolated canine tracheal smooth muscle. Am Rev Respir Dis 1988; 138: 780-783.

229. Farmer SG, Hay DWP. Airway epithelial modulation of smooth muscle function: the evidence for epitheliumderived inhibitory factor. In: Farmer SG, Hay DWP, eds. The Airway Epithelium: Physiology, Pathophysiology and Pharmacology. New York, Marcel Dekker Inc., 1991, pp. 437-471.

230. Robbins RA, Hamel FG, Floreani AA, et al. Bovine bronchial epithelial cells metabolize L-arginine to Lcitruline: possible role of nitric oxide synthase. Life Sci 1993; 52: 709-716.

231. Stuart-Smith K. Heterogeneity in epithelium-dependent responses. Lung 1990; 168: 43-48.

232. Nadel JA, Borson DB. Modulation of neurogenic inflammation by neutral endopeptidase. Am Rev Respir Dis 1991; 143: S33-S36.

233. Borson DB, Brokaw JJ, Sekizawa K, McDonald DM, Nadel JA. Neutral endopeptidase and neurogenic inflammation in rats with respiratory infections. J Appl Physiol 1989; 66: 2653-2658.

234. Hay DW. Guinea-pig tracheal epithelium and endothelin. Eur J Pharmacol 1989; 171: 241-245.

235. Nogami M, Romberger DJ, Rennard SI, Toews ML. Transforming growth factor- $\beta_{1}$ modulates $\beta$-adrenergic receptor number and function in cultured human tracheal smooth muscle cells. Am J Physiol 1994; 266: L187-L191.

236. Nadel JA. Neutral endopeptidase modulates neurogenic inflammation. Eur Respir J 1991; 4: 745-754.

237. Nagae A, Abe M, Becker RP, Deddish PA, Skidgel RA, Erdös EG. High concentration of carboxypeptidase M in lungs: presence of the enzyme in alveolar Type I cells. Am J Respir Cell Mol Biol 1993; 9: 221-229.

238. Nadel JA. Regulation of neurogenic inflammation by neutral endopeptidase. Am Rev Respir Dis 1992; 145: S48-S52. 
239. Borson DB, Gruenert DC. Glucocorticoids induce neutral endopeptidase in transformed human tracheal epithelial cells. Am J Physiol 1991; 260: L83-L89.

240. Abe Y, Ogino S, Irifune M, et al. Histamine content, synthesis, and degradation in nasal mucosa and lung of guinea-pigs treated with toluene diisocyanate (TDI). Clin Exp Allergy 1993; 23: 512-517.

241. Nadel JA, Conrad DJ, Ueki IF, Schuster A, Sigal E. Immunocytochemical localization of arachidonate 15lipoxygenase in erythrocytes, leukocytes and airway cells. J Clin Invest 1991; 87: 1139-1145.

242. Robbins RA, Barnes PJ, Springall DR, et al. Expression of inducible nitric oxide synthase in human bronchial epithelial cells. Biochem Biophys Res Commun 1994; 203: 209-218.

243. Moncada S, Higgs EA. Endogenous nitric oxide: physiology, pathology, and clinical relevance. Eur J Clin Invest 1991; 21: 361-374.

244. Punjabi CJ, Laskin JD, Pendino KJ, Goller NL, Durham SK, Lashkin DL. Production of nitric oxide by rat Type II pneumocytes: increased expression of inducible nitric oxide synthase following inhalation of a pulmonary irritant. Am J Respir Cell Mol Biol 1994; 11: 165172.

245. Juhasz I, Murphy GF, Yan H, Herlyn M, Albelda S. Regulation of extracellular matrix proteins and integrin cell substratum adhesion receptors on epithelium during cutaneous human wound healing in vivo. Am J Pathol 1993; 143: 1458-1469.

246. Clark RAF, Lanigan JM, DellaPelle P, Manseau E, Dvorak $\mathrm{HF}$, Colvin RB. Fibronectin and fibrin provide a provisional matrix for epidermal cell migration during wound reepithelialization. J Invest Derm 1982; 79: 264-269.

247. Rickard K, Taylor J, Rennard SI, Spurzem JR. Migration of bovine bronchial epithelial cells to extracellular matrix components. Am J Respir Cell Mol Biol 1993; 8: 63-68.

248. Shoji S, Ertl RF, Linder J, Romberger DJ, Rennard SI. Bronchial epithelial cells produce chemotactic activity for bronchial epithelial cells. Am Rev Respir Dis 1990; 141: 218-225.

249. Horiba K, Fukuda Y, Kanno S, Yamanaka N. Fibronectin receptor in epithelial and mesenchymal cells in wound healing of rat trachea. Am Rev Respir Dis 1993; 147: A47.

250. French-Constant C, Van De Water L, Dvorak H, Hynes R. Reappearance of an embryonic pattern of fibronectin splicing during wound healing in the adult rat. J Cell Biol 1989; 109: 903-914.

251. Schwarzbauer JE. Alternative splicing of fibronectin: three variants, three functions. Bio Essays 1991; 13: 527-533.

252. Hershberger RP, Culp LA. Cell-type-specific expression of alternatively spliced human fibronectin IIICS mRNAs. Mol Cell Biol 1990; 10: 662-671.

253. Wang A, Cohen DS, Palmer E, Sheppard D. Polarized regulation of fibronectin secretion and alternative splicing by transforming growth factor- $\beta$. J Biol Chem 1991; 266: 15598-15601.

254. Elices MJ, Tsai V, Strahl D, et al. Expression and functional significance of alternatively spliced CS1 fibronectin in rheumatoid arthritis microvasculature. $J$ Clin Invest 1994; 93: 405-416.

255. Sporn MB, Roberts AB, Shull JH, Smith JM, Ward JM Polypeptide transforming growth factors isolated from bovine sources and used for wound healing in vivo. Science 1983; 219: 1329-1331.
256. Ignotz RA, Massague J. Transforming growth factor- $\beta$ stimulates the expression of fibronectin and collagen and their incorporation into extracellular matrix. J Biol Chem 1986; 261: 4337-4345.

257. Romberger D, Beckmann J, Claassen L, Ertl R, Rennard S. Modulation of fibronectin production of bovine bronchial epithelial cells by transforming growth factorbeta. Am J Respir Cell Mol Biol 1992; 7: 149-155.

258. Sacco O, Romberger D, Rizzino A, Beckmann J, Rennard S, Spurzem J. Spontaneous production of TGF- $\beta_{2}$ by primary cultures of bronchial epithelial cells: effects on cell behavior in vitro. J Clin Invest 1992; 90: 13791385.

259. Noah T, Paradiso A, Madden M, McKinnon K, Devlin $\mathrm{R}$. The response of a human bronchial epithelial cell line to histamine: intracellular calcium changes and extracellular release. Am J Respir Cell Mol Biol 1991; 5: 484-492.

260. Ito H, Romberger DJ, Rennard SI, Spurzem JR. TNFalpha enhances bronchial epithelial cell migration and attachment to fibronectin. Am Rev Respir Dis 1993; 147: A46.

261. Zahm J, Chevillard M, Puchelle E. Wound repair of human surface respiratory epithelium. Am J Respir Cell Mol Biology 1991; 5: 242-248.

262. Zahm JM, Pierrot D, Puchelle E. Fibronectin-mediated effect of epidermal growth factor on the wound healing of human respiratory epithelium in culture. Am Rev Respir Dis 1993; 147: A47.

263. Spurzem JR, Sacco O, Rickard KA, Rennard SI. Transforming growth factor-beta increases adhesion but not migration of bovine bronchial epithelial cells to matrix proteins. J Lab Clin Med 1993; 122: 92-102.

264. Sheppard D, Erle D, Busk M, Pytela R. Identification of novel airway epithelial integrins using the homologybased polymerase chain reaction. Chest 1992; 101: 49S.

265. Rennard SI, Beckmann J, Daughton D, et al. The role of airway epithelium in cellular migration. In: Farmer SG, Hay DWP, eds. The Airway Epithelium: Physiology, Pathophysiology and Pharmacology. New York, Marcel Dekker Inc., 1991; pp. 117-127.

266. Rickard KA, Shoji S, Spurzem JR, Rennard SI. Attachment characteristics of bovine bronchial epithelial cells to extracellular matrix components. Am J Respir Cell Mol Biol 1991; 4: 440-448.

267. Kennan KP, Combs JW, McDowell EM. Regeneration of hamster tracheal epithelium after mechanical injury. 1. Focal lesions: quantitative morphologic study of cell proliferation. Virchows Arch 1982; 41: 193-214.

268. Jetten AM, Vollberg TM, Nervi C, George MD. Positive and negative regulation of proliferation and differentiation in tracheobronchial epithelial cells. Am Rev Respir Dis 1990; 142: S36-S39.

269. Nettesheim P, Ferriola P, Steigerwalt R, Robertson A, Rundhaug J. The role of growth factors in the regulation of proliferation of tracheobronchial epithelium. Chest 1992; 101: 23S-24S.

270. Masui T, Wakefield LM, Lechner JF, La Veck MA, Sporn MB, Harris CC. Type- $\beta$ transforming growth factor is the primary differentiation-inducing serum factor for normal human bronchial epithelial cells. Proc Natl Acad Sci USA 1986; 83: 2438-2442.

271. Jetten AM, Shirley JE, Stoner G. Regulation of proliferation and differentiation of respiratory tract epithelial cells by TGF- $\beta$. Exp Cell Res 1986; 167: 539-549.

272. Miller LA, Cheng LZ, Wu R. Inhibition of epidermal 
growth factor-like growth factor secretion in tracheobronchial epithelial cells. Cancer Res 1993; 53: 25272533.

273. Plopper CG, Dungworth DL, Tyler WS. Pulmonary lesions in rats exposed to ozone. Am J Pathol 1973; 71: 375-394.

274. Evans MJ, Cabral-Anderson LJ, Freeman G. Transformation of alveolar Type 2 cells to Type 1 cells following exposure to $\mathrm{NO}_{2}$. Exp Mol Pathol 1975; 20: 11-23.

275. Martin TR, Chi EY, Covert DS, et al. Comparative effects of inhaled volcanic ash and quartz in rats. Am Rev Respir Dis 1983; 128: 144-152.

276. Long EG, Smith JS, Meier JL. Attachment of Pneumocystis carinii to rat pneumocytes. Lab Invest 1986; 54: 609-615.

277. Kumar RK, Truscott JY, Rhodes GC, Lykke AWJ. Type 2 pneumocyte responses to cyclophosphamide-induced pulmonary injury: functional and morphological correlation. Br J Exp Pathol 1988; 69: 69-80.

278. Jones AW, Reeve NL. Ultrastructural study of bleomycininduced pulmonary changes in mice. J Pathol 1978; 124: 227-233.

279. Coulombe PA, Filion PR, Cote MG. Biphasic mode of epithelial regeneration in murine pulmonary alveoli. Anal Quant Cytol Histol 1986; 8: 263-266.

280. Witschi H. Proliferation of Type II alveolar cells: a review of common responses in toxic lung injury. Toxicology 1976: 5; 267-277.

281. Spencer H. Pathology of the lung. 4th edn. Philadelphia, W.B. Saunders Co., 1985.

282. Mason RJ, Williams MC. Alveolar Type II cells. In: Crystal RG, West JB, eds. The Lung, Scientific Foundations. New York, Raven Press, 1991: pp. 235-246.

283. Infeld MD, Brennan JA, Davis PB. Human tracheobronchial epithelial cells direct migration of lung fibroblasts in three-dimensional collagen gels. Am J Physiol 1992; 262: L535-L541.

284. Nakamura Y, Tate L, Ertl R, Kawamoto M, et al. Bovine bronchial epithelial cells stimulate fibroblast DNA synthesis. Am Rev Respir Dis 1993; 147: A278.

285. Kawamoto M, Nakamura Y, Tate L, Ertl RF, Romberger DJ, Rennard SI. Modulation of fibroblast Type I collagen and fibronectin production by bronchial epithelial cells. Am Rev Respir Dis 1992; 145: A842.

286. Shoji S, Rickard KA, Ertl RF, Robbins RA, Linder J, Rennard SI. Bronchial epithelial cells produce lung fibroblast chemotactic factor: fibronectin. Am J Respir Cell Mol Biol 1989; 1: 13-20.

287. Postlethwaite AE, Keski-Oja J, Moses HL, Kang AH. Stimulation of the chemotactic migration of human fibroblasts by transforming growth factor- $\beta$. J Exp Med 1987; 165: 251-256.

288. Holtzman MJ. Epithelial cell regulation of arachidonic acid oxygenation. In: Farmer SG, Hay DWP, eds. The Airway Epithelium: Physiology, Pathophysiology and Pharmacology. New York, Marcel Dekker Inc., 1991: Vol. 55; pp. 65-94.

289. McGowan SE. Extracellular matrix and the regulation of lung development and repair. FASEB J 1992; 6: 2895-2904.

290. Koizumi S, Ertl R, Rennard S. Bronchial epithelial cells stimulate fibroblast proliferation. Am Rev Respir Dis 1991; 143: A526.

291. Nakamura, Y, Ertl R, Tate L, Rennard SI. Endotoxin stimulates bovine bronchial epithelial cells to release stimulatory factor and inhibitory factor for fibroblast proliferation: role of prostaglandin $\mathrm{E}_{2}$. Eur Respir $J$ 1993; 6: 241S.

292. Xing Z, Jordana M, Braciak T, Ohtoshi T, Gauldie J. Lipopolysaccharide induces expression of granulocyte/ macrophage colony-stimulating factor, interleukin-8, and interleukin-6 in human nasal, but not lung, fibroblasts: evidence for hereogeneity within the respiratory tract. Am J Respir Cell Mol Biol 1993; 9: 255-263.

293. Finkbeiner WE. General features of respiratory pathology. In: Saunders WB, Murray JF, Nadel JA, eds. Textbook of Respiratory Medicine. Philadelphia, Saunders, 1994; 1: pp. 419-468.

294. Niederman MS, Fein AM. Sepsis syndrome, the adult respiratory distress syndrome, and nosocomial pneumonia: a common clinical sequence. Clin Chest Med 1990; 11: 633-656.

295. Schwarz MI, King TE, Cherniack RM. General principles and diagnostic approach to the interstitial lung diseases. In: Saunders WB, Murray JF, Nadel JA, eds. Textbook of Respiratory Medicine. Philadelphia, Saunders, 1991; 1: pp. 1803-1826.

296. Golden JA. Interstitial (diffuse parenchymal) lung disease: physiology. In: Baum GE, Wolinsky E, eds. Textbook of Pulmonary Diseases. Boston. Little, Brown and Co., 1994; 2: pp. 1051-1066.

297. Sobonya RE. The morphologic basis for diseases of airways obstruction. In: Baum GE, Wolinsky E, eds. Textbook of Pulmonary Diseases. Boston. Little, Brown and Co., 1994; 11: 955-971.

298. Chia MM, Gazdar AF, Carbone DP, Minna JD. Biology of lung cancer. In: Saunders WB, Murray JF, Nadel JA, eds. Textbook of Respiratory Medicine. Philadelphia, Saunders, 1994; 1: pp. 1485-1503.

299. Goswami SK, Kivity S, Marom Z. Erythromycin inhibits respiratory glycoconjugate secretion from human airways in vitro. Am Rev Respir Dis 1990; 141: 72-78.

300. Crystal RG. Gene therapy strategies for pulmonary disease. Am J Med 1992; 92: 448-528.

301. Anderson WF. Human gene therapy. Science 1992; 265 : 808-813.

302. Flotte TR, Afione SA, Solow R, et al. Expression of the cystic fibrosis transmembrane conductance regulator from a novel adeno-associated virus promoter. J Biol Chem 1993; 268: 3781-3790.

303. Rosenfeld MA, Yoshimura K, Trapnell BC, et al. In vivo transfer of the human cystic fibrosis transmembrane conductance regulator gene to the airway epithelium. Cell 1992; 68: 143-155.

304. Zabner J, Couture LA, Gregory RJ, Graham SM, Smith $\mathrm{AE}$, Welsh MJ. Adenovirus-mediated gene transfer transiently corrects the chloride transport defect in nasal epithelia of patients with cystic fibrosis. Cell 1993; 75: 207-216.

305. Smith BT, Post M. Fibroblast-pneumonocyte factor. Am J Physiol 1989; 257: L174-L178. 